\title{
Olympic Waterfronts: An Evaluation of Wasted Opportunities and Lasting Legacies
}

\author{
Pedro Janela Pinto (D) and Gustavo Lopes dos Santos * (D) \\ Centre for Innovation in Territory, Urbanism and Architecture (CiTUA), Instituto Superior Técnico, \\ University of Lisbon, 1049-001 Lisbon, Portugal; pedrojpinto@berkeley.edu \\ * Correspondence: gustavosantos@tecnico.ulisboa.pt
}

Citation: Pinto, P.J.; Lopes dos Santos, G. Olympic Waterfronts: An Evaluation of Wasted Opportunities and Lasting Legacies. Sustainability 2022, 14, 1968. https://doi.org/ $10.3390 /$ su14041968

Academic Editors: Eduardo Medeiros, Paulo Tormenta Pinto, Ana Brandão and Agnieszka Bieda

Received: 31 December 2021

Accepted: 7 February 2022

Published: 9 February 2022

Publisher's Note: MDPI stays neutral with regard to jurisdictional claims in published maps and institutional affiliations.

Copyright: (C) 2022 by the authors. Licensee MDPI, Basel, Switzerland. This article is an open access article distributed under the terms and conditions of the Creative Commons Attribution (CC BY) license (https:// creativecommons.org/licenses/by/ $4.0 /)$.

\begin{abstract}
Mega-events such as the Olympic Games are powerful tools for city-branding and urban development, carrying the ability to create lasting physical, political, social, and economic legacies. Waterfront redevelopment has become a primary mechanism for revitalizing urban spaces, especially through brownfield requalification, and the Olympics have not been indifferent to this trend. Several recent editions have engaged in the rehabilitation of urban waterfronts. To analyze common mistakes that may impair the quality of these interventions, we apply a revised version of a binary evaluation tool to nine such Olympic Waterfronts, starting with Barcelona 1992, assessing their contexts, budgets, programs, plans, and environmental integration. The results show that the Olympic Waterfront can drastically change the image of the city, greatly contributing to the perceived success of the event's legacy and creating new urban centralities. However, the inadequate management in the planning, delivery and, especially, legacy stages of the event can compromise this "Olympic Effect". The test application of the evaluation tool proved successful in the context of mega-event planning and postevent transformation. It could potentially be useful in informing present and future decision-making regarding waterfront regeneration projects by highlighting pressure-points that, if not addressed, may hinder the future success of the interventions.
\end{abstract}

Keywords: urban waterfronts; urban redevelopment; Olympic Games; mega-event planning; Barcelona 1992; Athens 2004; Beijing 2008; London 2012; Sochi 2014; Rio de Janeiro 2016

\section{Introduction}

While frequently marred in controversy, the Olympic Games have been catalysts of rapid urban development projects, fostering interventions that would otherwise hardly be implemented [1]. Due to their particular characteristics, they have the power to trigger unique economic, social, and environmental benefits, through urban renewal, also providing "entrepreneurial cities" the unique branding opportunity to boost their global status [2] At the same time, the hosting of such events presents unquestionable inherent risks, as they are associated with demanding schedules and requirements, hardly matching any city's strategic planning and often draining public funds, incurring significant opportunity costs [3-5].

The scale and character of urban interventions in the context of the Olympic Games has been evolving since the modern revival of the event, with special relevance from the 1960s onwards, despite some stagnation in the early 1980s [6]. In particular, the Games of the XXV Olympiad in Barcelona marked a turning point, not only for mega-event-led urban regeneration but also for urban strategic planning. The 'Barcelona model' and the associated planning for the 1992 Olympics represented a template of sorts for the next host cities, which more prominently started considering event planning as a valid instrument in their urban development strategic approaches, realizing the event's city-branding potential for the dissemination of local culture and identity, and to enhance and consolidate their global profiles and economic competitiveness [1,6-9]. 
The ever-growing scale of the Olympics and of the associated urban interventions eventually led to sustainability concerns [10], for which event owners, planners, and organizers became increasingly aware. At the turn of the millennium and following the Winter Olympics of Albertville 1992 and Lillehammer 1994, the mitigation of environmental issues and the creation of green legacies became one of the top priorities of the event's stakeholders, highly influencing mega-event planning and Olympic-related urban projects [11]. However, the development of new specialized and high-quality sports centers integrated in green parks and environments has triggered even larger and more costly interventions [12], often resulting in significant land consumption for the creation of single-purpose areas, and generating social problems and conflicts between local communities, organizations, and stakeholders [13]. Different planning approaches of each host city have had varying results, with some being able to match event requirements with local needs (strategic planning, infrastructures, venues, etc.), while others have let event planning supersede, or even compromise, the city's planning needs.

The incorporation of large urban-redevelopment projects as central elements of each host city's Olympic legacy became significant after Barcelona, often through the regeneration of urban waterfronts. This cannot be dissociated from a broader trend in urban renewal: waterfront regeneration, as a whole, has become one of the most important forms of urban intervention, triggered by the relocation of industries, ports, and linear infrastructure $[14,15]$. Brownfields, located in central sites within metropolitan areas, on the shores of rivers, lakes, and seas, are often perceived as prime real-estate opportunities within dense urban fabrics [16]. Large urban regeneration projects have become desirable investments but frequently lead to unequal balancing of desired outcomes among different stakeholders, fostering land-use conflicts and the commodification of public space [17], often failing to fully meet the challenges and opportunities for improvement at the urban waterfront [18].

Where the two phenomena meet-Olympic urbanism and waterfront regeneration-is at what we call the "Olympic Waterfront". These are, evidently, waterfront spaces, often brownfields, that were selected for the development of Olympic sites. At their best, they could draw from the exceptional character and popularity of the Olympics and combine it with the unique environment and opportunities of urban waterfronts, generating attractive locations with the potential to set off entire urban renewal processes at the city scale. In other words, there is a complementarity between the potentials of both types of projects: while waterfronts provide cities with dynamic and multi-purpose urban areas for local populations, the Olympic Games offer a unique momentum for their promotion, also mobilizing stakeholders to deeply and collectively engage in the development of the project. Already promising waterfront spaces, prime for regeneration and naturally instilled with a unique character granted by the presence of the waterbody, can be boosted by the "Olympic Effect" (see [7]), attracting a level of attention (and investment) not often devoted to the creation of quality public space or public facilities.

However, despite this enormous potential, some recent Olympic Waterfronts have resulted in public spaces that are quite underwhelming. They present diverse problems that, ultimately, may also derive from the specificities of Olympic projects, or from typical pitfalls of waterfront interventions. The combination of the two might even suggest the existence of a set of potential problems that may affect Olympic Waterfronts in particular. Similarly to their unique potentials, they may face specific challenges, resulting from the unique combination of mega-event planning-designed to serve over a very narrow timeframe and with inflexible schedules - and the creation of diversified and vibrant urban waterfronts, a process commonly developed over decades. If not adequately addressed, these two ends may be at odds.

Such a hypothesis begs the question of what actions have led to less-than-successful outcomes. Is there a concept of an Olympic Waterfront project that differs in character from both Olympic and waterfront projects? And what are its distinct elements of (in)success? Our objective in this paper is to explore the specific nature of Olympic Waterfronts through a test application, in a set of case studies, of a previously developed, yet improved, evaluation 
tool. Additionally, being the first published application of the tool, we test whether it can be successfully applied to a set of real-life case studies and used for comparison and pattern recognition (see [18]). This evaluation draws from the identification of common mistakes present in Olympic Waterfronts, The Wrongs, complementing it with an assessment of best practices, which we hope could inform policymakers in future developments of similar nature. If properly adapted to the context of each specific study, this tool can serve for the assessment of waterfront interventions or other mega-projects, especially for comparative purposes to assist in decision-making. In the next section, we describe our methodology, and in Section 3, the results are presented individually for nine case studies. In Section 4, a comparison of the case studies is carried out and the most common mistakes present in Olympic Waterfront projects are identified through the cross-examination of results from all case studies. We conclude by deriving a set of findings on the elements that may impair the outcomes of Olympic waterfront regeneration efforts and suggest how to address such mistakes.

\section{Methodology: The Fit of Olympic Waterfronts}

Pinto and Kondolf proposed an evaluation tool for the quick assessment and identification of elements of waterfront projects that have failed or are prone to failure [18]. It is meant as a quick assessment tool, designed for quick comparability, and based on readily assessable criteria and data. For the purpose of this research, we preserved the original classification system based on five typical Wrongs often present in waterfront interventions, which are further divided into five criteria each (Figure 1). The assessment tool was, nevertheless, significantly adjusted:

- $\quad$ Being its first real-life application, the assessment tool required adaptations so as to allow a comparative analysis of case studies. We had to define methods for objective evaluation of each criterium, based on credible external sources and direct observation;

- A first step was taken to transform the mostly qualitative and theoretical evaluation tool into a quantitative one. For each criterium, a simple binary classification was adopted, where -1 indicates that the specific problem is present while 0 indicates it is not. This was decided for the sake of objectivity, as a more nuanced evaluation along a sliding scale would introduce new elements of subjectivity and complexity to each independent assessment ( 25 criteria applied to each of the 9 case studies);

- The criteria were named, to be better understandable; they were revised, in favor of objectivity and to avoid overlap; and they were adjusted, to better reflect the specifics of Olympic sites, with some criteria being refocused on programmatic and planning issues, typical of the mega-event nature of the Games and their sites. Detailed descriptions of the criteria were created, and we identify limitations in regard to the methods adopted in their evaluation and in regard to their application to the specific context of Olympic Waterfronts (Appendix A);

- Some of the Wrongs were renamed and their descriptions adjusted to increase objectivity and avoid overlap.

The evaluation of the case studies involved a review of literature and media (scientific publications, consistent traditional media reporting, and official Olympic files). Time-lapse imagery analysis observed the sites' transformation dynamics using Google Earth's historical imagery, and map analysis looked at planning and transit maps and aerial imagery to observe current and planned features. Finally, virtual site survey resorted to Google Street View to further survey the site's current condition. To increase the robustness of this assessment, criteria were evaluated only if supporting data were found, being rated 0 otherwise. As such, we opted to only consider that a certain problem was present in a project whenever we found credible references to it, or if it was directly observable in timelapse aerial imagery and street view.

The methodology was applied to nine case studies in eight Olympic cities, selected through the following criteria: (i) contemporaneity, starting with Barcelona 1992, which marked a significant shift in the importance of strategic planning in the context of the 
Olympic Games, as addressed earlier; (ii) location, considering only Olympic Waterfront urban interventions in close proximity to sizeable bodies of water (rivers, lakes, or seashores); (iii) coherence, selecting the areas with significant urban interventions, that is, not limited to the construction or renovation of sports facilities but including a rehabilitation of an intervention area. Each case study's evaluation, as well as the criteria and justification, are presented in Appendix B. Such an evaluation regards the site itself, from the moment of the Olympic intervention and its post-event evolution as an urban waterfront space, up to the present day, and not its performance during the Olympic event.

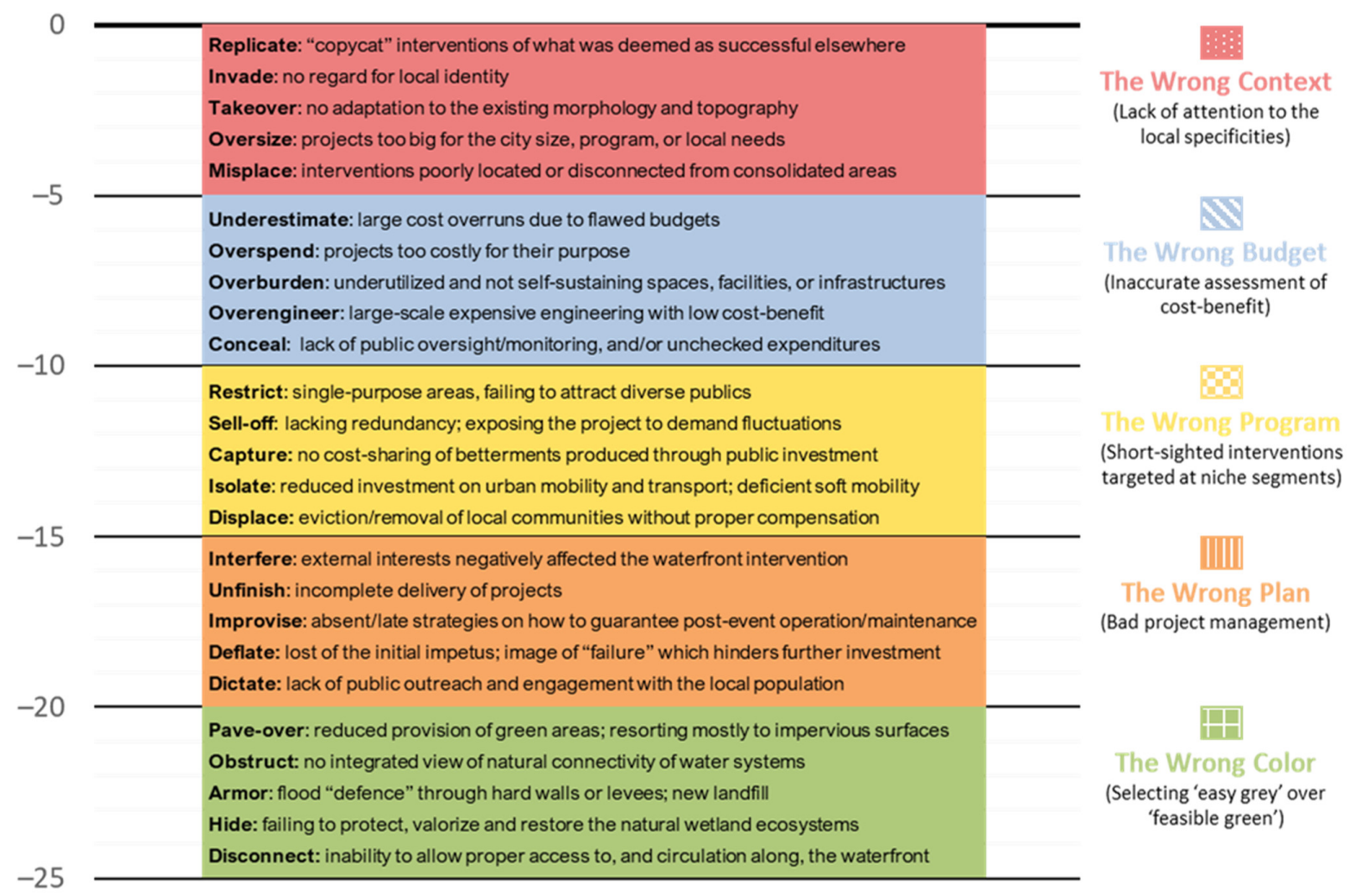

Figure 1. The Wrongs and respective criteria. Own creation based on [18].

\section{Olympic Waterfronts: The Case Studies}

Each of the nine Olympic Waterfronts (Figure 2) is presented in this section, with a brief overview of the event's history and motivations, and an analysis of the results of our methodology. All evaluations mentioned in text are in reference to, and justified in, Appendix B. In the end, an overview of Tokyo 2020, Paris 2024, and Brisbane 2032 complements the analysis, focusing on recent trends of mega-event planning derived from sustainability concerns and the implementation of the Olympic Agenda 2020.

\subsection{Barcelona 1992: Parc de Mar}

Following its successful hosting of Expo 1929 and the 1992 Olympic Games, Barcelona is often presented as a role model for mega-event urban planning and waterfront regeneration $[7,19]$. The city used the hosting of the 1992 Olympic Games as a stated opportunity to be repositioned as a global city and to pursue a vast program of urban regeneration, which included the complete reconfiguration of the seafront [20]. Major roads and railways were put in tunnels and allowed unimpeded access between central neighborhoods and the urban beaches. The central element was the area of Parc de Mar (Figure 3), a former industrial and illegal settlement seafront area, separated from the remaining urban fabric by a railway. After the Games, the area became a vital and dynamic centrality of the city, combining residential areas with economic, leisure, and tourism activities [1]. 


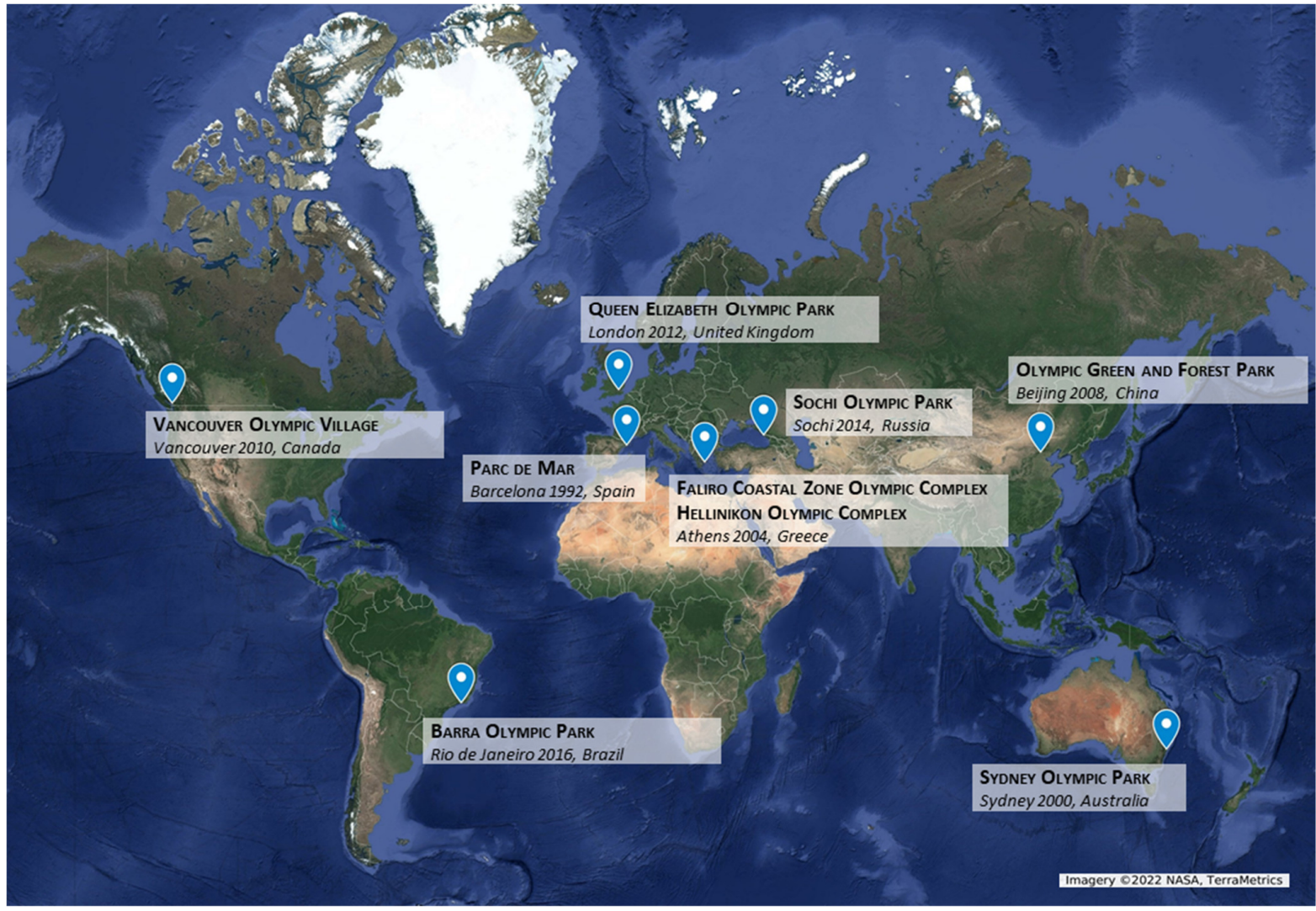

Figure 2. Location of the nine case studies of Olympic Waterfronts. Own creation. Maps Data: Google, (02022 NASA, TerraMetrics.

PARC DE MAR - BARCELONA 1992

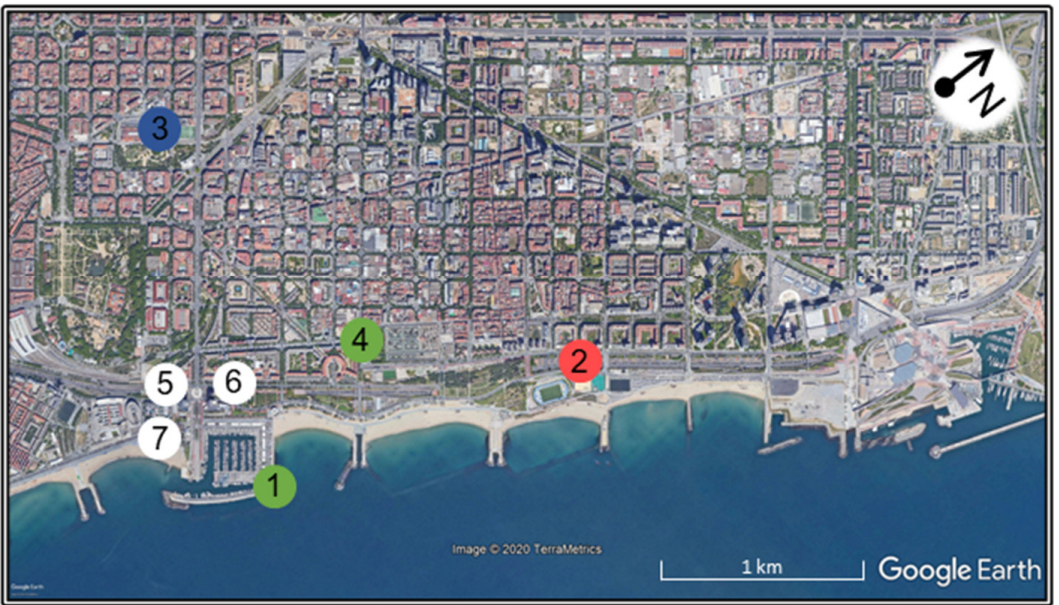

1-Olympic Harbour

2- Pavelló de la Mar Bella

3 - Estaciódel Nord

4-Olympic Village

\section{5- Hotel Arts}

6-Mapfre Tower

7 - Golden Fish

Existing - no permanent works

- New - previously planned

- Temporary

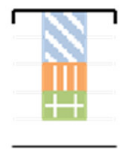

- Existing - permanent works required

- New - additional for the Game

\begin{tabular}{|c|c|c|c|c|c|c|c|}
\hline The Wrong Context & The Wrong Budget & & The Wrong Program & The Wrong Plan & & The Wrong Color & \\
\hline Invade & Overspend & $\checkmark$ & Sell-off & Unfinish & & Obstruct & $\checkmark$ \\
\hline Oversize & Overengineer & & Isolate & Deflate & & Hide & \\
\hline Misplace & Conceal & & Displace & Dictate & $\checkmark$ & Disconnect & \\
\hline
\end{tabular}

Figure 3. Parc de Mar: venues/facilities, and classification. Own creation. Maps Data: Google, @2020 TerraMetrics. 
The Parc de Mar intervention did not significantly alter the existing shoreline but requalified the urban beaches and removed precarious structures built over them. A large promenade was created along the beachfront, and level crossings were created along the shoreline, connecting it to the Barceloneta and, over the buried highway and railway, to Poble Nou. Here, the new Vila Olímpica neighborhood converted a large industrial site, following the street pattern characteristic of the Eixample and seamlessly integrating into the consolidated urban fabric [8].

Barcelona is lauded for framing the interventions in a broader, and long-term, existing planning strategy that built on Ildefonso Cerdà's plan for the Eixample of Barcelona. Hosting the Olympics represented an opportunity and justification for the costly and complex restructuring of the city's waterfront [9]. One of its fundamental aspects was the transformation of the Ronda del Litoral, an urban highway, which was partially converted into a trench-tunnel system. Although very expensive and overrunning cost estimates (Underestimate, Overspend), the intervention allowed unimpeded street-level connection between the Vila Olímpica and adjacent blocks with the seafront. More recently, it has been noted that the project was decided and implemented with no participative or consultative process (Dictate), which was then not uncommon for large project management. Additionally, the project was able to remediate urban beaches and make them fully accessible to the public, but extensive erosion protection works were required, as the natural longshore circulation of sediments was further disturbed (Obstruct). While infrastructure works represented a huge investment, these served the city as a whole and were not planned specifically for temporary access to the site during the Olympics.

Overall, Parc de Mar was exemplary in its integration into a broader city-wide strategy of urban renewal and city marketing. This allowed for a seamless integration into the urban fabric and the city's planning strategies (perfect zero scores on The Wrong Context and The Wrong Program), including the expansion of public transit network to allow optimal access to the site, proposing a mix of land uses that granted the project with resilience in the face of real-estate market fluctuations [8]. It ultimately created a system of public spaces, regional facilities, and green areas that serves the new neighborhoods and the city and allows the unimpeded use of a seafront promenade for leisure and recreation.

\subsection{Sydney 2000: Sydney Olympic Park}

Matching the International Olympic Committee's decision to make "environment" one of the three main strands of Olympism, the organizing committee for the 2000 Sydney Olympics committed to deliver "Green Games". As such, a massive sports area was built at Homebush Bay (Figure 4), bringing the opportunity to remediate heavy pollution problems in the former brownfield, and promote its regeneration, while also creating a large natural park [1]. Together with the adjacent Olympic Village, the intervention resulted in a new suburb of Greater Western Sydney, the Olympic Park.

The location was criticized for its somewhat remote location (Misplace), which required the construction of a public transit line with issues of self-sustainability and high maintenance costs (Overengineer) and may have limited the demand of certain public spaces and facilities (Overburden) [21,22]. While adhering to somewhat classic zoning, with clear separation of the very large sports complex, residential areas, and the large urban park, which compromised walkability and urban integration, and restricted mixed use (Invade, Oversize, Restrict), it nevertheless succeeded in creating a new centrality within Sydney Metro, along the shores of the harbor [23]. This is especially true after a thorough revision of post-event transition plans [24,25], which led to a new urban development strategy that mitigated the limitations imposed by the Olympic event (Interfere) that had, for a time, compromised the reuse and vitality of some zones (Deflate).

Despite these limitations, the Olympic Park contains several large green areas of citywide importance, including the Bicentennial Park and Wentworth Commons, while other areas were carefully designed to preserve wetlands (such as the Badu Mangroves). This preoccupation with the preservation, restoration, and valorization of wetlands makes the 
Sydney Olympic Park the earliest, and one of only three case studies, with no significant problems regarding The Wrong Color. As such, with its system of green spaces and consideration for existing natural values, the site holds up to the "Green Games" commitment. Nevertheless, its location, far from central Sydney, rendered some facilities and public transport routes underutilized, and its zoning issues and "growth pains" justify less perfect scores in The Wrong Context, The Wrong Budget, and The Wrong Plan categories.

SYDNEY OLYMPIC PARK - SYDNEY 2000

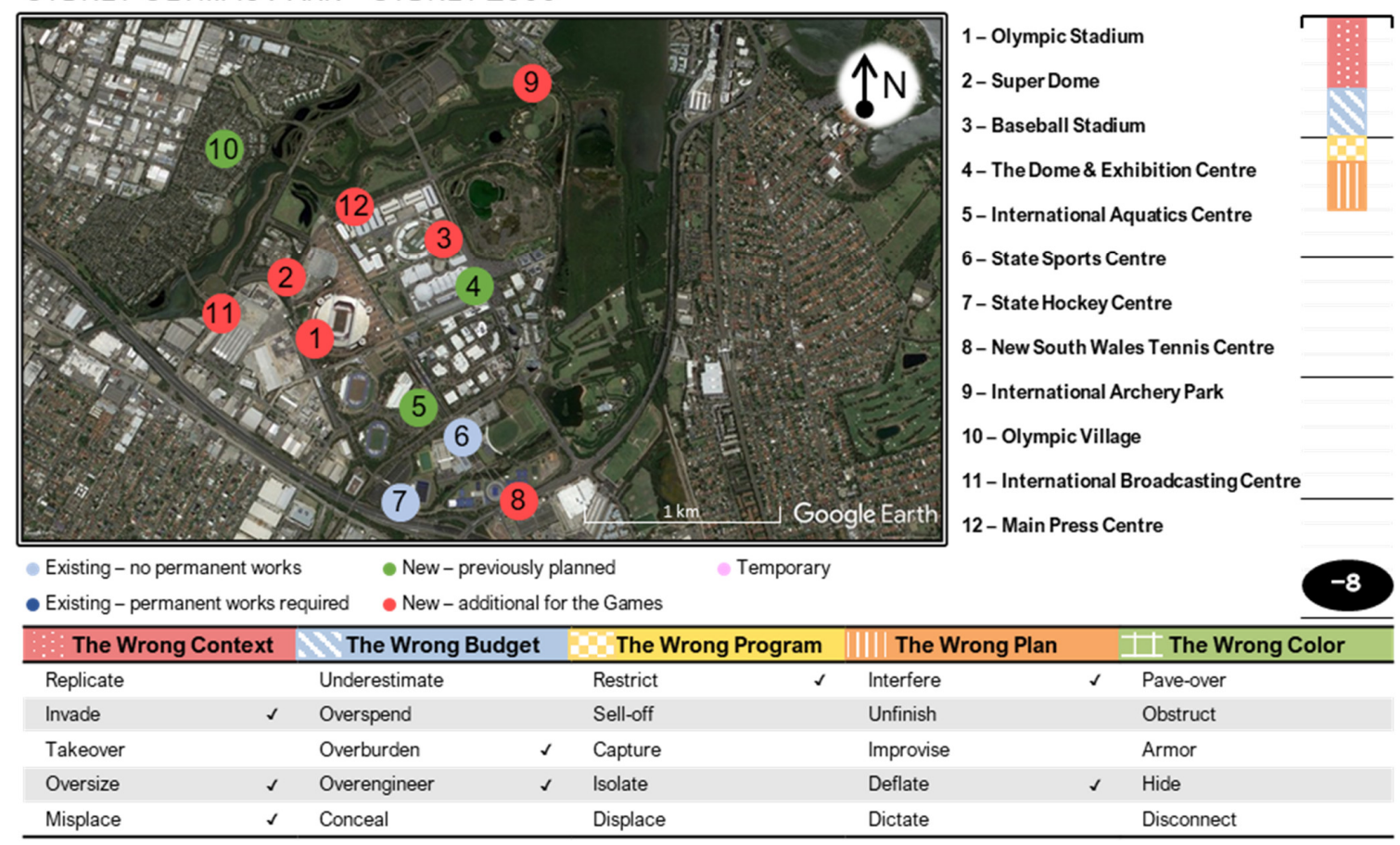

Figure 4. Sydney Olympic Park: venues/facilities, and classification. Own creation. Maps Data: Google.

\subsection{Athens 2004: Faliro Coastal Zone Olympic Complex and Hellinikon Olympic Complex}

A century after the first Modern Olympic Games, taking place in Athens, the city intended to host the 1996 "Centennial Games" to celebrate the Greek roots of both the Ancient and Modern Olympics. After losing that bid to Atlanta, mostly for lacking vital infrastructure to guarantee a successful delivery of the event, Athens submitted a new bid for 2004, promising to massively improve its transport system and heavily relying on the concentration of Olympic activities in the Faliro coastal area. Following a series of lastminute changes (Interfere), immersed in controversy, the final plans resulted in the spread of venues between the seafront areas of Faliro (Figure 5) and of the former Hellinikon Airport (Figure 6) [1].

The initial objective of the Faliro Bay project was to break the barrier between the waterfront and the Tzitzifies quarter by diverting and burying some sections of the coastal highway and giving direct access to the seafront. However, due to concerns of mass concentration during the Olympics, several of these facilities were rashly moved to Helliniko. After the Games, most of the Faliro site remained undeveloped and the burial of linear infrastructure was postponed (Unfinish) [1]. Following 14 years of stagnation, works have recently resumed and the project, with significant revisions, seems to be headed towards a successful conclusion [26,27]. The highway tunnels reconnecting Athens' urban fabric with the extensively remodeled landfill at the seafront (Takeover, Overengineer) will complement the already existing pedestrian crossover, giving access to the newly built Stavros Niarchos Cultural Center. The latter provides an anchor to the area, improving the attractiveness of what is expected to become a new centrality [28,29]. While the project is not particularly successful in restoring a more natural shoreline as it preserves and expands landfill and 
makes no provision to restore wetland habitat (Armor, Hide), a regionally-important ecological urban park is being created over the landfills, including areas for leisure, culture, and sports activities [30-32].

FAliro CoAstal Zone Olympic CompleX-Athens 2004

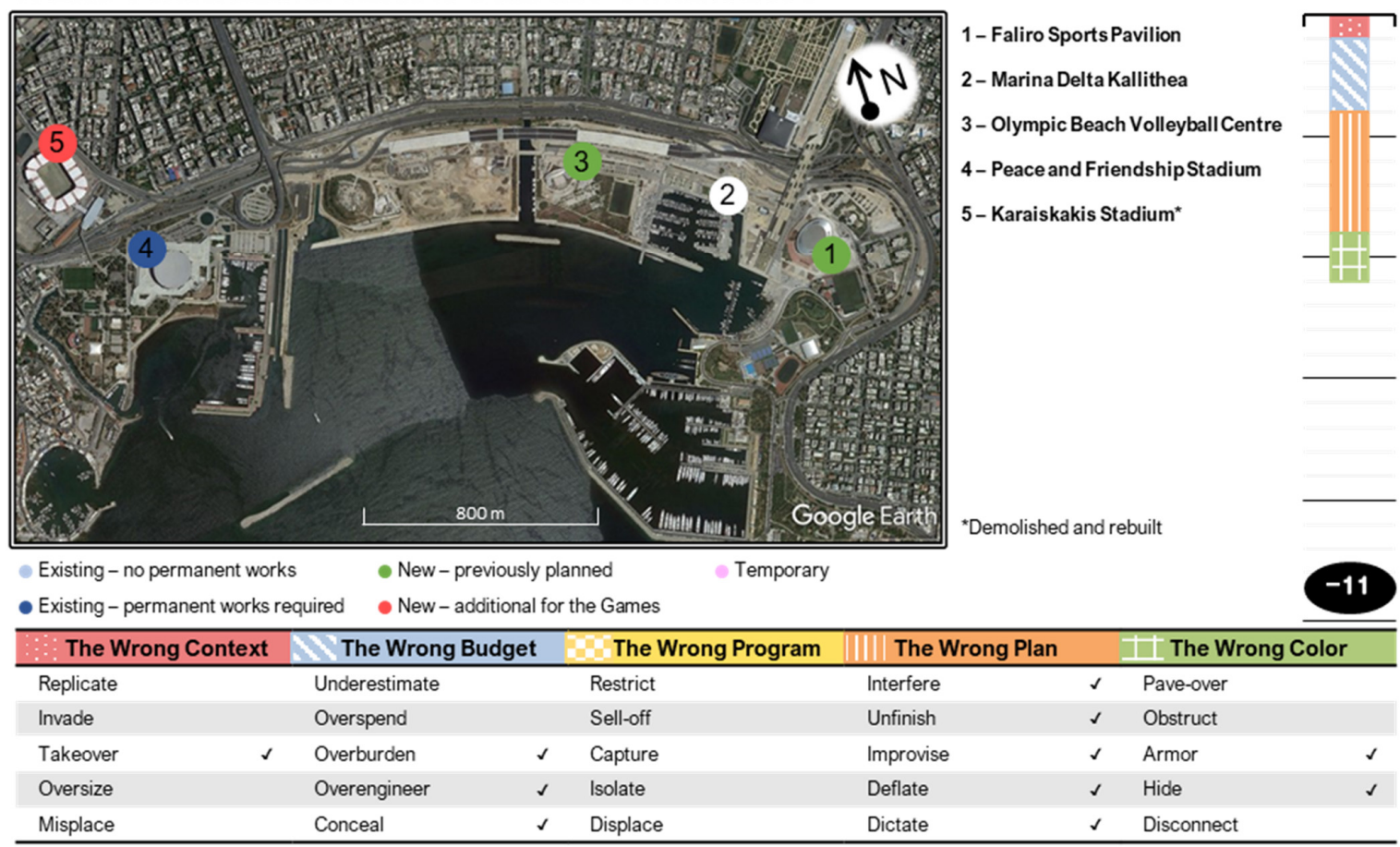

Figure 5. Faliro Coastal Zone Olympic Complex: venues/facilities, and classification. Own creation. Maps Data: Google.

HELLINIKON OLYMPIC COMPLEX-ATHENS 2004
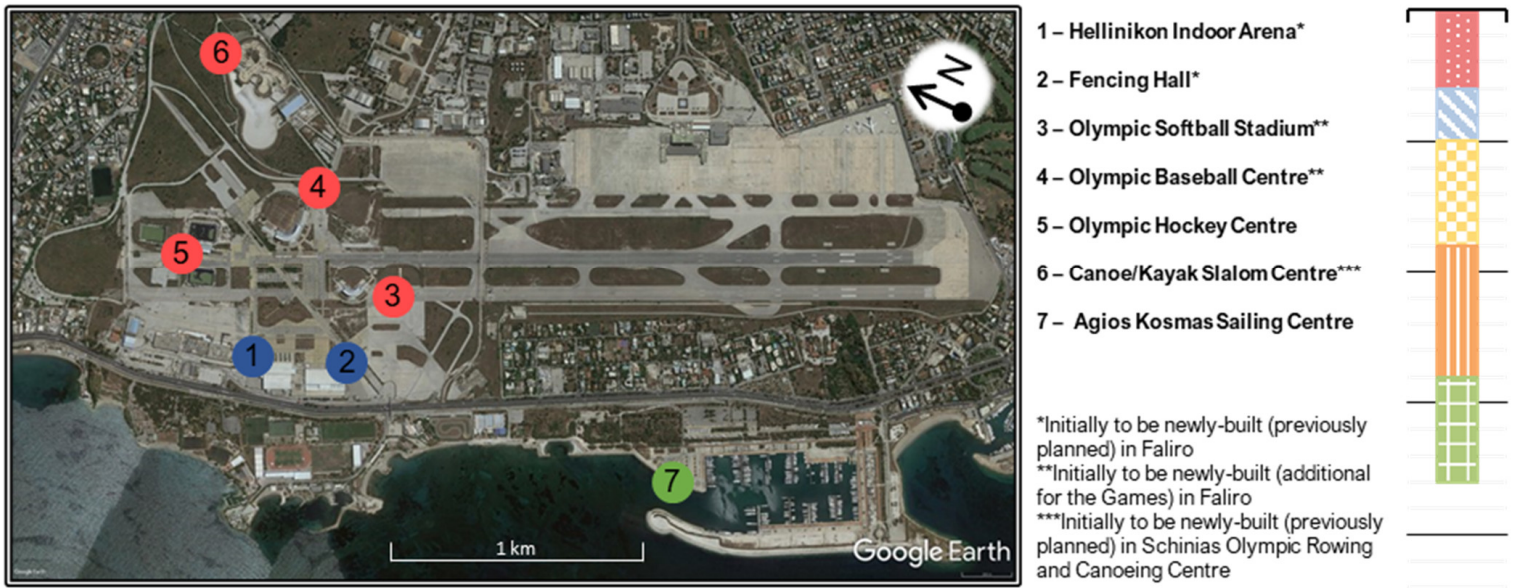

for the Games) in Faliro and Canoeing Centre

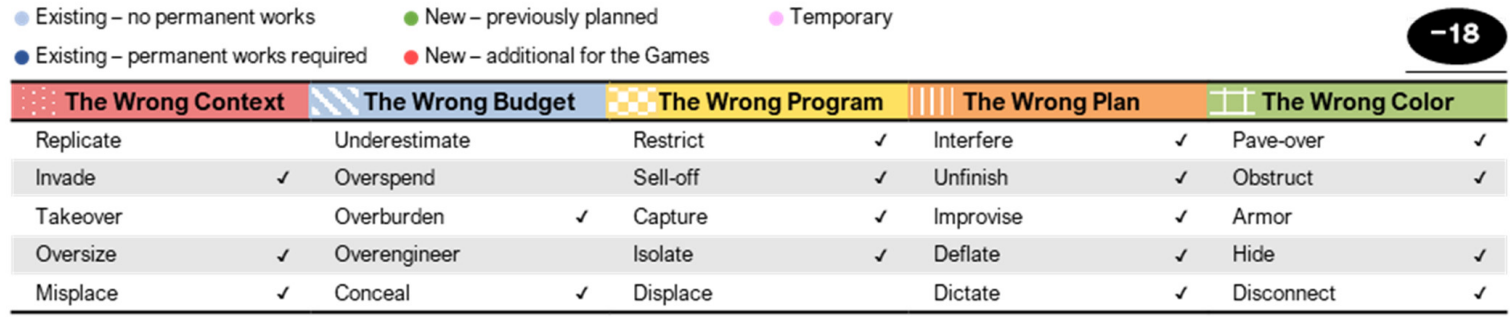

Figure 6. Hellinikon Olympic Complex: venues/facilities, and classification. Own creation. Maps Data: Google. 
Further east along the Aegean Sea front, the isolated and massive site of the old Hellinikon airport acted as a depository of sorts for the relocated venues, forcing rushed planning with little character and design (Invade, Oversize, Misplace). While the reuse of the site and several facilities was expected, the mix of uses (or lack thereof) condemned most of the site to a state of disrepair soon after the Games, with most of the venues not having a post-event purpose (The Wrong Program) [33,34]. The connection with the waterfront was not adequately addressed nor improved for the Games or afterwards, with linear barriers kept in place. The intervention also failed to remediate the airport's brownfield site, having yet to promote ecological restoration or the removal of the continuous impervious surfaces (The Wrong Colour). While long-debated projects for the site foresee the creation of a privately developed, and long awaited, large metropolitan park [35], these have seen an increasingly larger share of for-profit uses and shrinking public open areas (Capture, Interfere) $[27,33]$.

Both case studies show issues of The Wrong Plan, as the already fragile or inexistent plans for post-event development of the sites and operation of venues, seemingly lacking demand (Overburden) [36-38], were severely affected by changes of plans, bureaucracies and, especially, deep economic crisis (Improvise, Deflate) [1,39]. In large part, these can be attributed to the late relocation of venues to Hellinikon, which resulted in an impromptu last-minute solution for that site and ultimately affected Faliro's coherence. These cases perfectly illustrate how a lack of resilience to externalities can influence expected urban outcomes, with funds being redirected from an existing sophisticated plan to a rushed and improvised one. This affected Faliro's redundancy and diversification, created a new problem at the Hellinikon site, and compromised the integration of both within existing urban fabric.

\subsection{Beijing 2008: Olympic Green and Forest Park}

The "Efficiency Games", in Beijing, were recognized as so not only because of its majesty and organizing competence but also because of its ecologically friendly approach, targeting the mitigation of air pollution, the improvement of sewage systems and wastewater treatment, the promotion of energy efficiency in the Olympic venues and village, and the creation of green areas such as the new Olympic Green and Forest Park (Figure 7) [1]. This large forest park is indeed symbolic of what the intervention tried to achieve: to create urban spaces and green areas that fulfilled needs already identified by the local administration. Beijing is a dense and sprawling city, where farmland has been sacrificed in recent decades to urban development. Setting aside a large area and creating the city's largest green area was, therefore, a major objective [40]. The Games are also seen as an example of city-branding through mega-events, within a broader effort to assert Beijing as a global city [41,42]. As a part of this rebranding effort, a whole new district, designed to create a new centrality within the city, was erected around the Olympic Green, surrounding an artificial lake.

The landscaping of this area required extensive terraforming and the impoundment of the headwaters of the Yangshan river, then a small creek (Takeover, Obstruct). These and other large-scale operations incurred severe direct costs-at the time, second only to Barcelona (Overspend) - also triggering high operation costs and issues with the selfsustainability of some venues, buildings, and technological solutions (Overburden, Overengineer) $[43,44]$. The construction of the Olympic Park required extensive residential displacement, with decisions being made in a strictly top-down fashion and with no public consultation or oversight (Displace, Dictate, Conceal) [45].

Nevertheless, while performing poorly on The Wrong Budget, the intervention is much more successful in the other areas. The urban project has created a valued new centrality in the city, and the overall implementation and management of the post-event transformation was swift and relatively painless, namely in its real-estate components, and in the creation of parks and facilities of regional and national significance [46,47]. The Olympic Green and Forest Park stretches along the Yangshan River, which forms its backbone, supported by a 
pedestrian network that takes full advantage of the proximity to the water and ecosystems. As such, while man-made, this "river" is very successful in bringing the water element to the fore in structuring the new urban centrality. The Park has been praised for recreating extensive artificial wetlands, providing much-needed habitat and recreation areas within the dense metropolitan region.

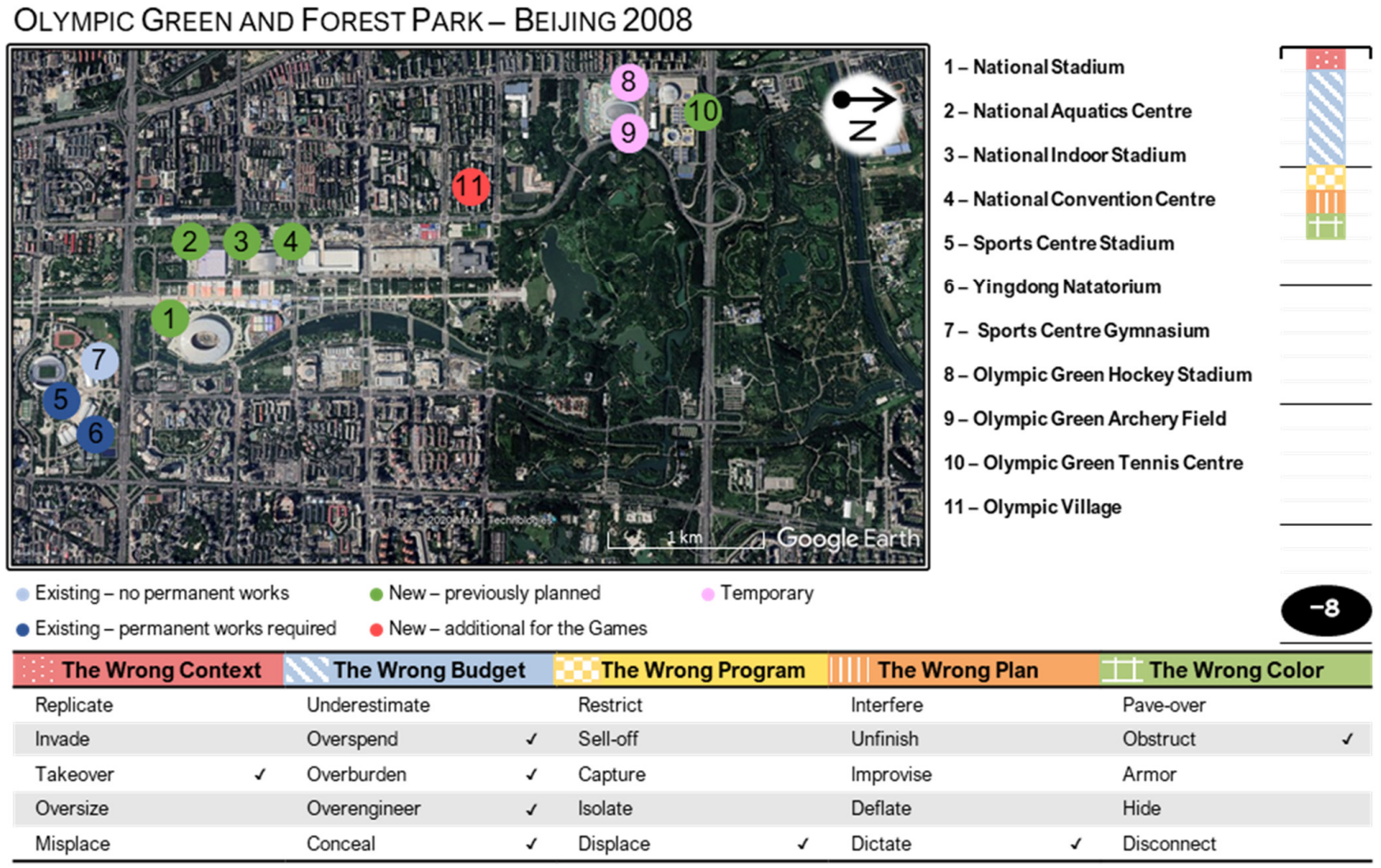

Figure 7. Olympic Green and Forest Park: venues/facilities, and classification. Own creation. Maps Data: Google, @2020 MaxarTechnologies.

\subsection{Vancouver 2010: Vancouver Olympic Village}

Vancouver 2010 was committed to delivering the first "Sustainable Games", focusing on topics of social inclusiveness and post-event legacies for everyone [1]. The Olympic Village, located at the southeast end of False Creek (Figure 8), was promoted as the "greenest" housing project in Canada, encompassing high-tech and "eco-friendly" solutions for rainwater collection and renewable energy, green roofs, and infrastructure for soft mobility [48]. To address the city's social housing needs and to mitigate Games-led evictions in the neighboring Downtown Eastside quarter, the project was also expected to deliver 33\% of the units in affordable schemes $[49,50]$.

Being centrally located and in a prime waterfront area of the city, the project showed great potential for urban renewal with a strong social inclusion component. Nonetheless, its association with the Olympic Games ended up backfiring as, to guarantee its delivery in time, the project's financing model deviated from what was expected (Interfere). From early on, major decisions took place behind closed doors and, in particular, the choice of developer was deemed suspicious due to its contested capability to successfully deliver such a high-tech project (Conceal) [51]. This was confirmed when the 2008 economic crisis made it impossible for the developer to complete the project, forcing the government to intervene and assume a large part of the financing and economic losses (Capture) [52]. To ensure viability, a larger share of the blocks had to be sold at market prices, thus sacrificing a significant number of affordable housing units (Improvise). In the end, only $2.5 \%$ of affordable housing was delivered, complemented by another $8 \%$ of different non-profit schemes [50]. 


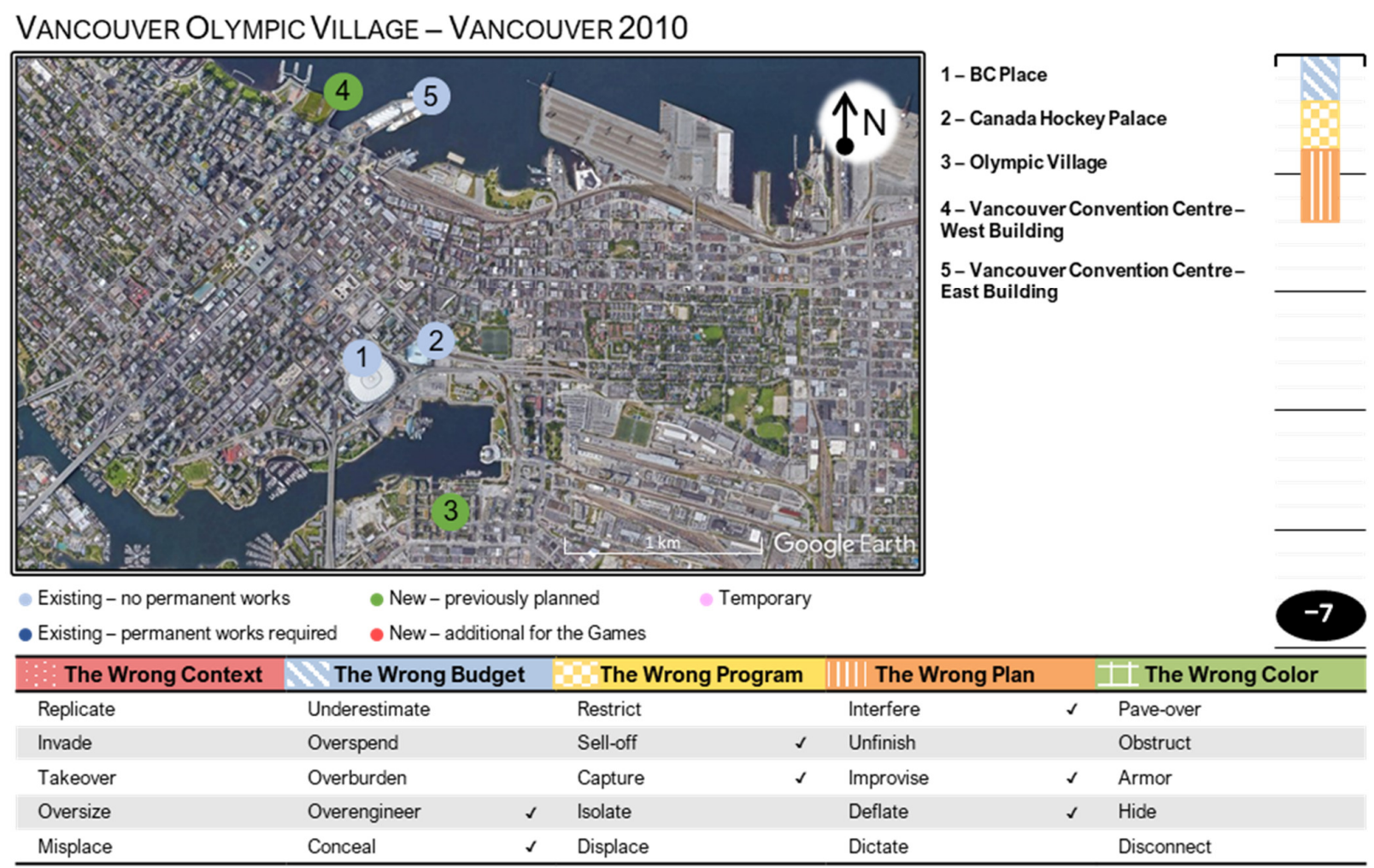

Figure 8. Vancouver Olympic Village: venues/facilities, and classification. Own creation. Maps Data: Google.

Together with the economic crisis, these hurdles also affected the final product. Potential buyers were disappointed with its quality, much lower than expected and promised. Units took a long time to sell (Deflate), and market prices had to be significantly readjusted (a consequence of Sell-off) [51]. Moreover, the high-tech solutions, besides complexifying the project's delivery, proved difficult to operate and expensive to maintain (Overengineer), definitely not meeting either the standards of a luxury neighborhood or the financial prospects of the low-income households and tenants [48].

Despite its bad project management (The Wrong Plan), the Olympic Village is nowadays an evidently successful, yet gentrified, neighborhood, displaying innovative green urbanism solutions. Comprising attractive areas for commercial, touristic, and leisure activities, it ultimately successfully integrated into existing urban fabric, at least from the perspective of accessibility, namely through public transit, and for the provision of quality urban spaces, drawing people to the waterfront. Here, a promenade hosts elements of beachfront habitat restoration and provides continuous access to and along the shoreline.

\subsection{London 2012: Queen Elizabeth Olympic Park}

Planned at a time of increasing awareness for the Games' sustainability and legacy, the London Olympics made history for being the first edition to have a legacy plan in execution long before the hosting of the event, and for breaking the record of the number of temporary venues used [7]. The intervention carried out for the "Regeneration Games" completely transformed a decaying area of brownfield, which had mostly resulted from deindustrialization and the closing of the nearby London Docks, into a renewed urban centrality in Stratford, East London [1]. The Queen Elizabeth Olympic Park (Figure 9) now occupies the valley of the River Lea, providing one of London's less affluent neighborhoods with leisure and culture green areas, rooted on the river's canals, and facilities and infrastructure for a variety of commercial, business, and sports activities [53]. 


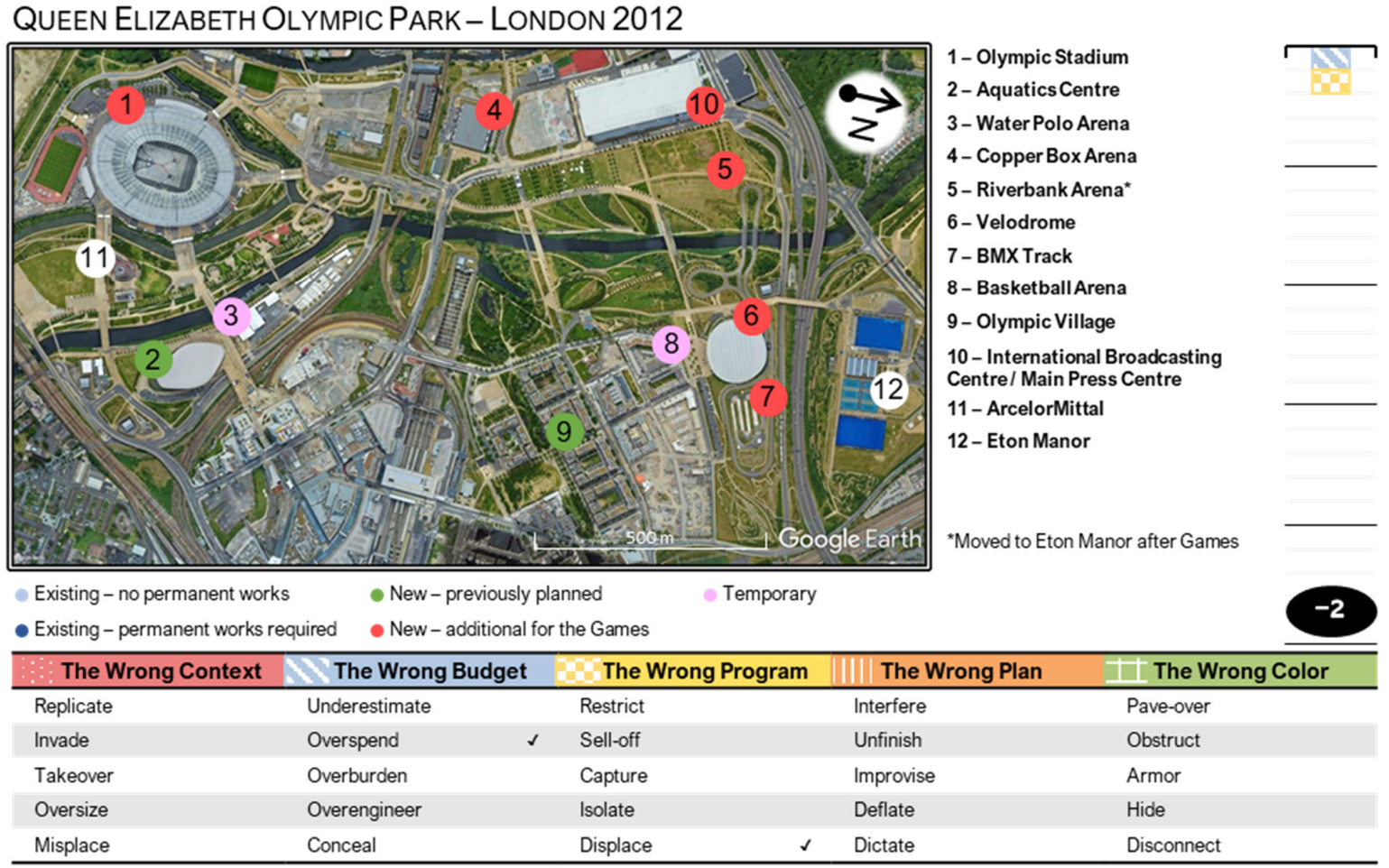

Figure 9. Queen Elizabeth Olympic Park: venues/facilities, and classification. Own creation. Maps Data: Google.

The project benefited from earlier experiences (Sydney's Olympic Park) and mistakes (London's own Docklands, Wembley Stadium, or Millennium Dome) and, like Barcelona, took the opportunity of the Games to, consciously, accelerate long-planned regeneration [54]. One of its strengths concerns how the new centrality was integrated into the existing valley and urban fabric, softly introducing facilities into a large green area while at the same time remediating natural environments. In order to increase the attractiveness and urban integration, new buildings and urban renewal were allowed at the project's edges and were complemented by amenities for commercial and business activities. Moreover, efficient transport infrastructure was provided for accessing the site, and soft mobility solutions were implemented, including an extensive system of pedestrian and cycling paths. This allowed for a well-developed mixture of uses, avoiding isolation and promoting the site's vitality [55].

While not yet completed, the Olympic Park already provides the area with muchneeded quality public spaces and has succeeded in the ecological improvement of the River Lea's valley. At the same time, it has been progressively regenerating the economic tissue of the run-down industrial quarter [55]. However, the project has faced two main criticisms, regarding its financial and social components. Firstly, while it showed a cost overrun lower than the average for Olympic projects, its initial and revised costs were way over the budgets of other editions of the Games (Overspend) [12]. Nonetheless, the massive interventions and respective expenses proved valuable and justifiable due to the current use of the site and were able to attract further investment for the continued development of housing and office space [53-55]. Secondly, and perhaps its most contested aspect, the project seems to have negatively affected the existing local low-income community. While a share of affordable housing is being delivered with every new housing development, it is clearly insufficient to match Stratford's extremely high demand for this type of accommodation [54]. Furthermore, the Olympic project resulted in a number of evictions (Displace), and property values skyrocketed. This has led to gentrification and is forcing locals to move away from the area $[49,56,57]$. This may be compromising one of the project's stated goals, which initially aimed at addressing the social issues affecting the local population. 


\subsection{Sochi 2014: Sochi Olympic Park}

The 2014 Winter Olympics were part of a strategy to develop and promote Sochi as a summer and winter tourism destination. It was controversial in the context of Russia's aggressive external policy (Interfere) and for adopting a strictly top-down decision-making process (Dictate) $[58,59]$. They have been especially criticized for being the most expensive Olympic Games ever (Overspend), and with the largest cost overruns (Underestimate), Winter or Summer, with escalating costs surpassing those of London 2012 [60]. The intervention, in the waterfront of the Black Sea, resulted in a new urban centrality, the Olympic Park (Figure 10), around $30 \mathrm{~km}$ away from the city center.

\section{SOCHI OLYMPIC PARK - SOCHI 2014}

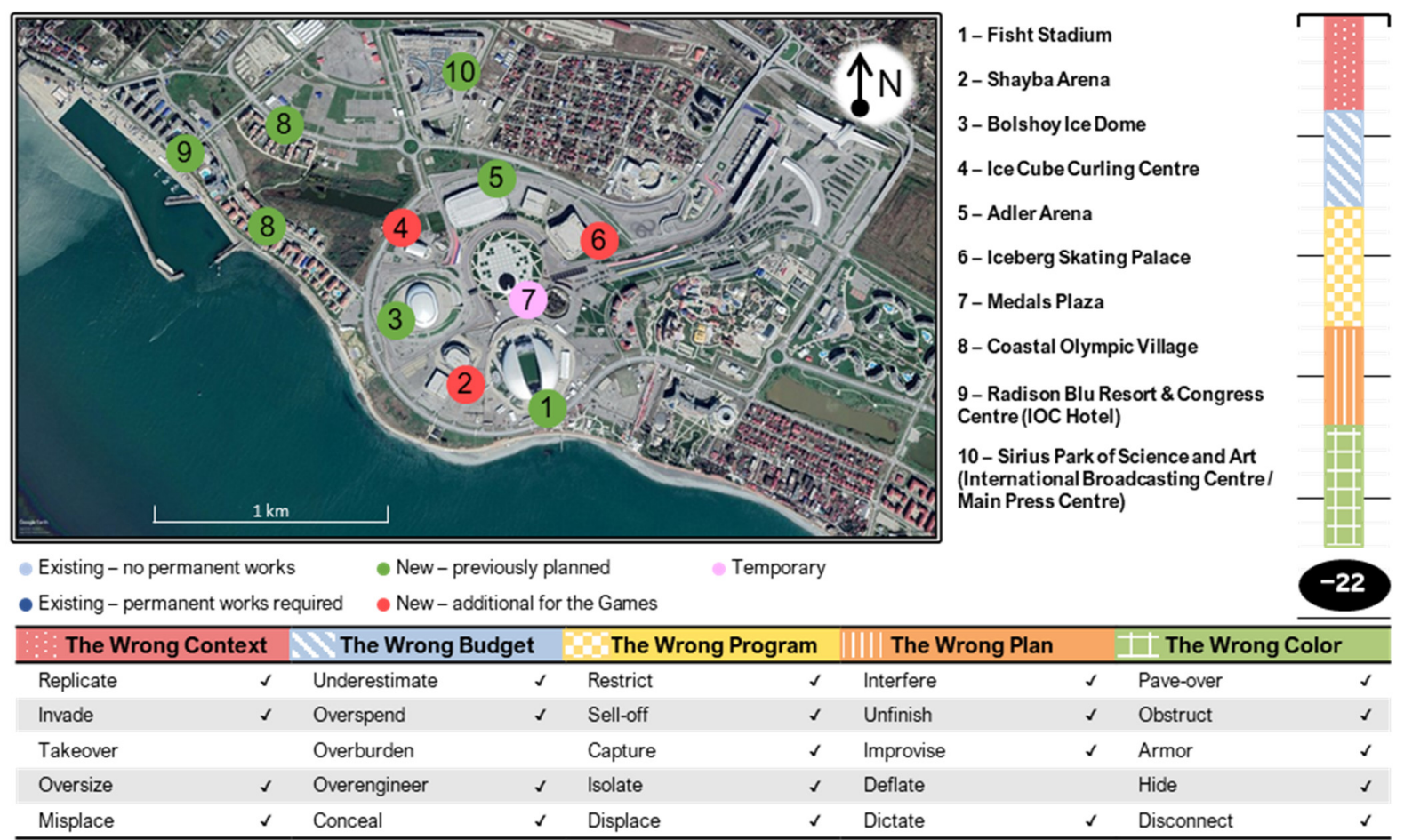

Figure 10. Sochi Olympic Park: venues/facilities, and classification. Own creation. Maps Data: Google, (C2020 MaxarTechnologies.

The somewhat remote location, relative to the city center (Misplace), has been criticized for its lack of real articulation with existing urban fabric and for awkwardly introducing architecture and urbanism replicated from other mega-events, dissonant with the surroundings (Invade, Replicate) [61,62]. The dense highway network forms considerable barriers to connectivity within, and between, the zones, and the train station is peripheral to the site and receives irregular service (Isolate). The park is also crisscrossed by the Sochi International Street Circuit, which breaks up street-level connectivity between the different sporting venues. Moreover, the connection between the different, monofunctional, zones is not pedestrian-friendly (Restrict) [63].

The Park comprises a very large number of sports and culture facilities, some of which were not removed as planned, ended up empty, or were adapted for uses other than the planned ones (Unfinish, Improvise). The result was an overlapping and redundant offer of sports venues and congress halls, with limited use to the local population (Oversize) [63]. The seafront development of the Olympic Village, next to beach tourism destinations and relatively close to mountain attractions, was transformed into hotels after the Games, thus not targeted at the city's populations or evicted residents (about 2000 families) (Displace) [64] (p. 210). The business model is perceived to have largely benefited private stakeholders 
(Sell-off), while the bulk of the large-scale investments were conducted by the public sector (Capture) [58,65].

The sports complex is centered around the Medals Plaza and closed onto itself in an inland location, rather than taking advantage of the close proximity to the Black Sea shoreline (Disconnect). It forms a vast, mostly impervious surface, partially constructed over former farmland and a system of creeks, canals, and wetlands, which were culverted and landfilled (Pave-over) rather than valorized and integrated into the urban project. Furthermore, the new port breakwater has disrupted longshore sediment transport (Obstruct, Hide) and pushing the new road network and Olympic Village to the seashore meant the introduction of a levee along the beaches, armoring the edge and encroaching on them (Armor).

The aim of the Olympic project was mostly to create Russia's prime resort for events and conferences, as well as an attractive all-season tourism destination. It did reinforce Sochi's status as "Russia's guesthouse" and, while it did increase domestic tourism to the city, it has been struggling to attract international visitors $[66,67]$. Despite resulting in one of the least diverse, mostly poorly connected, and least environmentally friendly Olympic Waterfronts of recent decades, it could be argued that neither the organizers nor the supporting decision-makers necessarily considered those as criteria for success.

\subsection{Rio 2016: Barra Olympic Park}

The Olympic Games in Rio were part of a strategy for hosting large-scale events in Brazil, including the 2007 Pan-American Games and the 2014 FIFA World Cup. The objective of strengthening the country's position as a tourism destination (and, in particular, the city of Rio de Janeiro) was clear, with marketing intensively showcasing "the city's natural scenic splendours and cultural heritage" [1] (p. 399). This was reflected in the location of the Barra Olympic Park (Figure 11), a large sports complex in the waterfront of the Jacarepagua Lagoon. Works for the redevelopment of the park started for the hosting of the Pan-American Games, in an attempt to take advantage of the prime location along the waterfront and the opportunity to renew the site of the abandoned Nelson Piquet International Race Track.

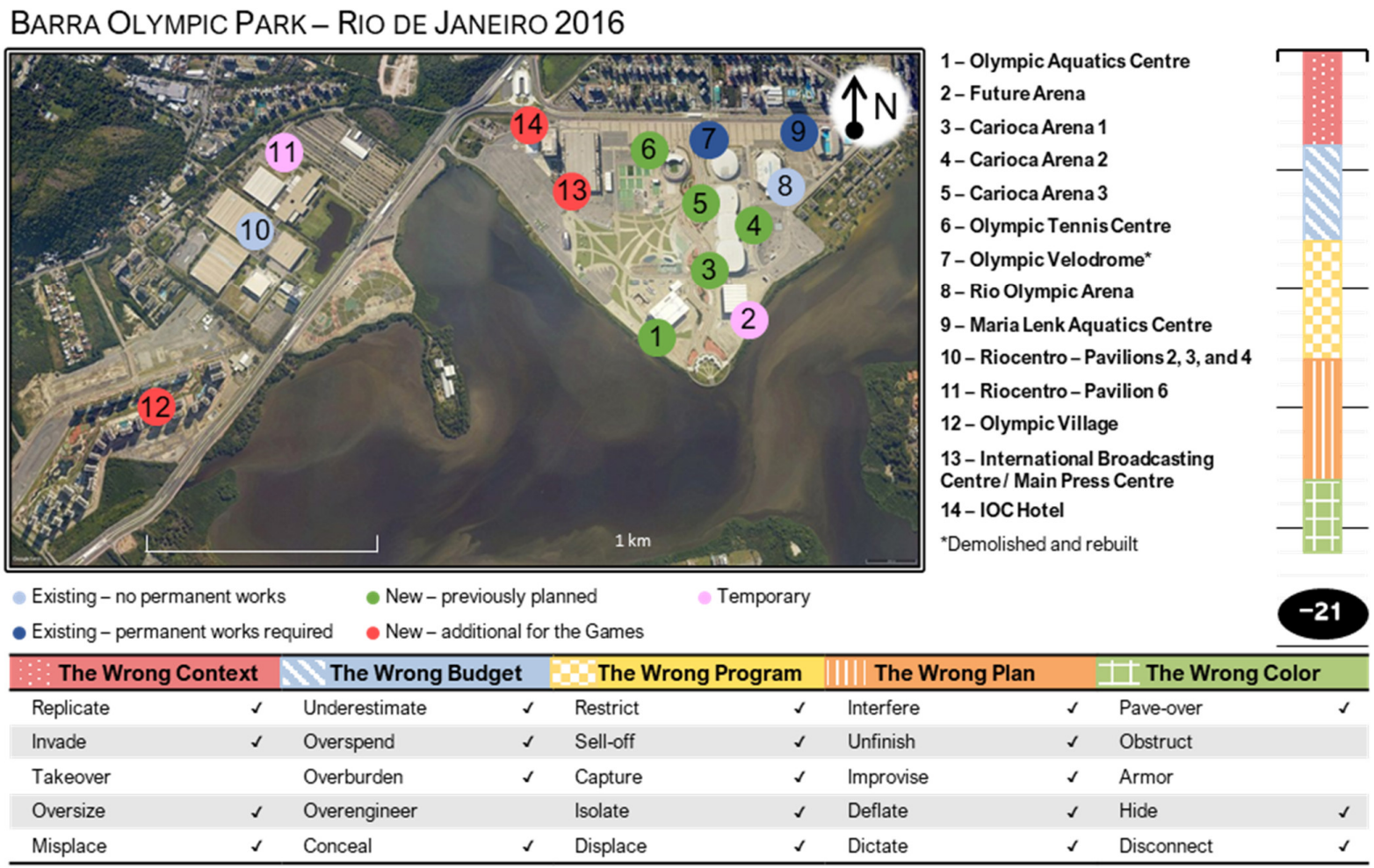

Figure 11. Barra Olympic Park: venues/facilities, and classification. Own creation. Maps Data: Google. 
The site selected for the Olympic Park, formed by the Barra Olímpica and the Olympic Village, is located in the suburb of Barra da Tijuca. This selection was criticized for choosing an affluent quarter of the city, with little connection to the city center (Misplace) [68]. The public transit system that was implemented (a branch-line of the Bus Rapid Transit system-BRT) provides indirect and lengthy connections to Rio's downtown (Isolate) $[69,70]$. Furthermore, clearing the site entailed the demolition of an informal settlement, the Vila Autódromo, with over 4000 residents being evicted (Displace) [71] (pp.1145). Both the site selection and demolitions have been criticized for a lack of transparency and participation (Dictate) [72].

While the Olympic Games effectively managed to initiate its redevelopment, with its most lasting element being the Via Olímpica, the resulting urban area has been marred by post-event funding issues, incomplete repurposing of several venues, and the abandonment of others (Unfinish) [73,74]. It failed to create a year-round centrality, only seeing spurts of activity related to the hosting of the "Rock In Rio" concerts or sporadic sports events. In 2017, the operation of the Olympic Park provided for only $2 \%$ of its maintenance costs (Overburden) [75].

The urban regeneration has been severely compromised by the economic crisis, and the urban redevelopment that was expected to occur following the guidelines of the Masterplan has been altered significantly with a new allotment project (Interfere) [76] (p. 695). The altered plan has been criticized for following the typical upper-class high-rise, closed condominium model, giving in to pressure by large developers and construction companies and marred by suspicions of corruption (Conceal, Restrict, Sell-off, Capture) [68,77,78]. Still, the market has not readily absorbed the few buildings that have been completed, and promoters of the Olympic Village (now rebranded Ilha Pura- "Pure Island") struggled to sell the apartments (Deflate, Improvise) [60,79]. As such, with its lack of a diverse, resilient, and wide-ranging urban renewal strategy, the project failed in all criteria of The Wrong Program and The Wrong Plan.

The project had little ambition in the restoration of the lagoon's natural ecosystems, and while the Masterplan idealized a wide rim of mangrove stretching along the shoreline, only a narrow strip was effectively preserved (Hide). The Barra Olympic Park is composed almost exclusively of impervious surfaces (Pave-over) and, while it did not expand preexisting landfill and flood defense structures, it did fail to create significant green parks and a network for soft mobility along the shoreline (Disconnect). Furthermore, the political context and economic crisis in Brazil effectively stalled further development of the project and inhibited the expected synergy with the surrounding urban fabric and the creation of a vibrant waterfront district.

\subsection{An Overview of the Present and Future of Olympic Waterfronts: Tokyo 2020, Paris 2024 and} Brisbane 2032

Tokyo 2020 was unique in the sense that it was severely affected by the COVID-19 crisis. It also stands-out for presenting one of the most compact venue masterplans, neither carrying out a massive urban regeneration nor creating a concentrated and distinctive Olympic space. Venue locations were scattered around existing urban districts, most of them in the Tokyo Bay district. This resulted in several, yet small, isolated waterfront interventions, some on the existing landfilled islands at Ariake. Most notorious among these is the newly built Olympic Village, which is now to be readapted to become a private neighborhood. Despite some drawbacks due to the pandemic, the luxury apartments, developed by public and private entities, seem to be headed to easily sell out [80], even if some features of the design, namely regarding its architecture, have been somewhat underwhelming [81]. Nevertheless, and although the system of artificial islands requires flood defense works that negatively affect natural environments, the project apportioned some of the limited space available to the creation of an urban green area and other public spaces, promoting recreation at the waterfront. 
While Tokyo 2020 was only partially influenced by the new Olympic Agenda 2020, Paris 2024, on the other hand, will be the first edition to fully adhere to its new recommendations. This Agenda aims at enhancing the Games' sustainability by radically changing some of its urban-related planning practices, including the significant reduction of the scope of urban interventions [82]. For Paris 2024, only two new venues are to be built, as well as a Media Village and the Athletes' Olympic Village. The latter, located in the communes of Saint-Denis, Ile Saint-Denis and Saint-Ouen, straddles an island on the Seine as well as its right bank. After the Games, the Village will be transformed into a neighborhood of mixed uses and classes, with a good provision of green spaces and "eco-friendly" solutions, intended to potentiate the integration of the river in the daily life of the new residents [83].

Although the Olympic Agenda 2020 is expected to maximize the use of existing venues, arguably few cities will be able to provide accommodation for 14,000 to 16,000 athletes and team officials in a single place without building new housing. Taking a quick glance at Brisbane 2032's Olympic Village, it will be developed in Northshore Hamilton, at the banks of the Brisbane River [84]. As such, it appears as though waterfront redevelopment will continue to be a trend in Olympic projects, even if at a smaller scale and, from now on, likely without the fanfare of iconic new sports venues. Such a trend validates the unique qualities of Olympic Waterfronts: even under the new guidelines, host cities still evidently appreciate the Games' potential for city-branding, and gladly combine it with the unique place-making opportunities provided by waterfront locations. However, since they tend to spur gentrification, new concerns and challenges demand solutions that efficiently integrate social sustainability and inclusiveness.

\section{Discussion}

Over the past three decades, more than half of the Olympics engaged in the redevelopment of Olympic Waterfronts, though with varying legacy outcomes. Smaller interventions, typically associated with the construction of Olympic Villages, such as in Vancouver and Tokyo, have created upscale residential neighborhoods. Larger interventions, such as Sydney and Beijing's Olympic Parks, left a positive and strong legacy of environmental regeneration at the city scale. However, while Sydney's intervention has partially failed to efficiently integrate land uses, Beijing's seems to have successfully created a long-needed urban centrality, providing an example of how some host cities appear to draw lessons from earlier events to inform their own projects. Similarly, the lower Lea Valley was completely revived by the Queen Elizabeth Olympic Park, which has catalyzed the urban redevelopment of East London. It drew on the earlier experiences of Sydney and Barcelona and, like Parc de Mar, the seamless integration of an Olympic Waterfront in the city's long-term urban regeneration efforts was crucial. As in Beijing, these case studies managed to successfully combine the potential of waterfront redevelopment with the "Olympic Effect", completely rebranding the image of the cities.

To the contrary, post-event use of Faliro shows how last-minute interference, coupled with vulnerability to economic cycles, can compromise well-meaning urban regeneration strategies, create stillborn and rushed development of alternatives (Hellinikon), and affect the urban legacy of the event. Economic cycles can be especially punishing for projects that lack clear visions and population engagement over the urban redevelopment outcome, especially regarding post-event transformation. This phenomenon severely affected the Barra Olympic Park too, although interference, political turmoil, and private interests can equally be blamed as major reasons for this failure. The Sochi Olympic Park shared similar issues but, while exceptionally expensive and failing to create an attractive and cohesive waterfront, it seems to be delivering on its extravagant legacy of city-branding.

Looking at the results presented in Figure 12, the limited focus on long-term urban regeneration strategies is apparent in the very poor scores of Sochi and Barra Olympic Parks, especially in The Wrong Program and The Wrong Plan. Both were thought of mostly from the perspective of city-branding events: hosting successful Olympics would create the marketing opportunity the decision-makers strived for; the urban waterfront regeneration 
effort, especially regarding its post-event transformation, appears to have been secondary, if not an after-thought. Barra succeeded in being less environmentally damaging, thus explaining the small difference in the overall evaluation. Hellinikon suffers from many of the same issues, but in this instance, mostly as a result of its rushed design and near-absence of plans for post-event reuse of the space. Its redeeming feature was avoiding The Wrong Budget, but that is reflected in the bland nature of the intervention: a "project" without a project. The selection of non-central locations, such as these three examples, seems to have a close association with less thoughtful urban design and project planning, which in turn has direct consequences over the project's ability to successfully integrate into the existing urban fabric and limiting its post-event reuse.

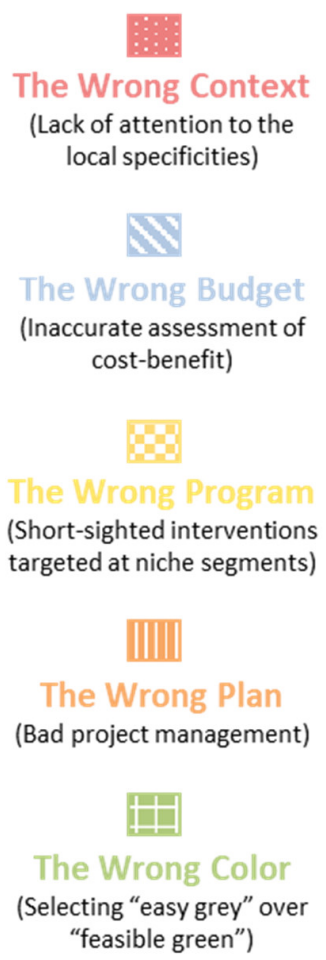

The Wrong Context
(Lack of attention to the local specificities)

The Wrong Program targeted at niche segments) "feasible green")
"fing "easy grey" over

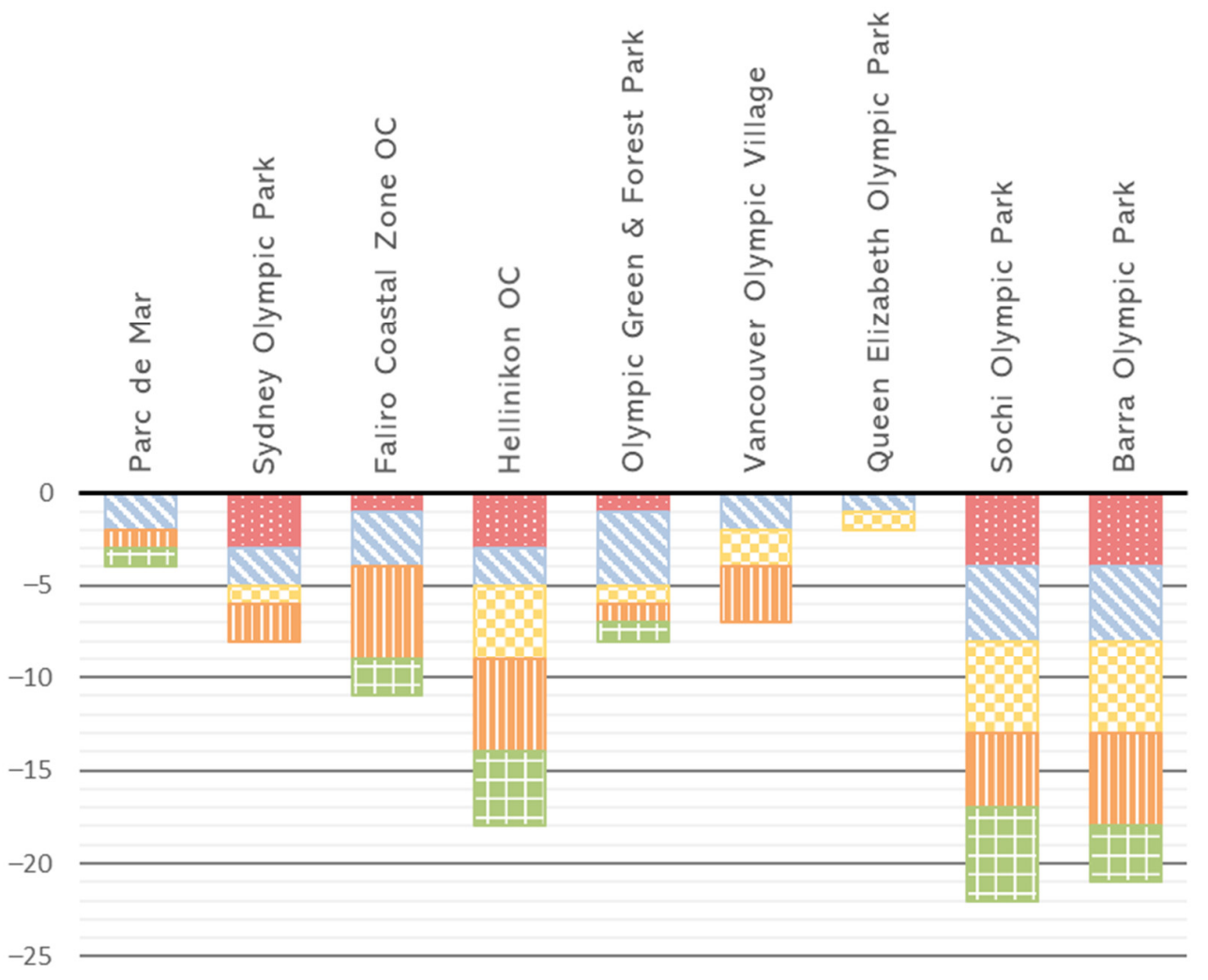

Figure 12. Comparative analysis of the nine case studies. Own creation.

Faliro's redevelopment was the main waterfront intervention of Athens 2004, but it suffered from chronic issues with implementation that have compromised its original concept. This is due to external interference, such as last-minute changes before the Olympics, and bureaucracies that hindered the post-event development of the project. Naturally, this cannot be dissociated from the deep economic crisis the country faced during this period, explaining its poor performance in The Wrong Plan. Openly inspired by Barcelona's model, it aimed at restoring central Athens' connection to the Aegean coastline; it will eventually succeed-only with over two decades of delays. Like Barcelona's Parc de Mar, the project's program is well conceived for its central location (avoiding The Wrong Context). It has been improved over time, aiming at creating a much-needed waterfront green area serving the city's dense core, and consolidating a venue to host sports and cultural events of national importance (a perfect zero score on The Wrong Program).

Sydney's Olympic Park also succeeded in creating a diverse program, which included quality sports, leisure, and residential areas. However, it was not quite successful in the creation of a fully integrated, mixed-use neighborhood-at least initially-possibly due to its suburban location. Its Wrong Context is only comparable to the least successful interventions overall-Sochi, Barra, and Hellinikon. The long distance to the city center may have affected the ability to sustain user-intensive venues, and the large, segregated 
zoning hindered synergies between uses and its full affirmation as a new centrality in the metropolitan area. Nevertheless, Sydney 2000 branded itself as the "Green Games" and more than delivered in that field, earning a perfect zero in The Wrong Color due to its green space provision and habitat restoration efforts. Its solutions served as an inspiration for the interventions of Beijing, London, and Vancouver. Like Sydney, the first two centered their Olympic Parks in large green areas, developed along restored river corridors, while the latter took inspiration from Sydney's Olympic Village to plan a smart, "eco-friendly" neighborhood.

Beijing took the opportunity to host the Summer Games as a huge city-branding effort-and a very costly one, "earning" four negative points in The Wrong Budget, comparable only to Rio and Sochi. However, unlike those, it managed to successfully avoid The Wrong Context and The Wrong Program by combining the creation of an easily accessible centrality with the provision of urban facilities and parks, already needed by the metropolitan area. Helped by a clear strategy and well-defined plan, it also successfully avoided problems with The Wrong Plan, very effectively managing the post-event transformation of the Olympic Park.

Contrastingly, Vancouver's main issues are related exactly to The Wrong Program, due to its lack of resilience in the face of an economic downturn, and The Wrong Plan, as it required extensive reformulation of post-event transformation strategies. While the Olympic Village would eventually become a successful, well-integrated neighborhood, it underwent significant changes that compromised its stated purpose of social sustainability. With its revised program, it ended-up, to the contrary, contributing to the gentrification of the surrounding area-although this phenomenon is frequent in Olympic interventions, having been observed in almost all case studies. It did deliver in creating a "green" neighborhood, especially regarding the creation of an accessible waterfront.

The best-scoring interventions (Barcelona's Parc de Mar and London's Queen Elizabeth Olympic Park) are also those that were arguably better integrated into long-term, farreaching urban development strategies for their territories. Both addressed problems the cities already intended to solve (regenerating large brownfield sites, retrofitting transport infrastructure) with the waterfront intervention acting as a catalyst and as an opportunity to create uses and venues for which the city already felt the need to create. Both of them also overspent, as Olympic events, most likely because they invested in elements that far surpassed, in scope, the direct needs to serve Olympic activities effectively. While not foregoing the city-branding aspect that all host cities hope to benefit from, these two cases, along with Beijing, very successfully took the opportunity to pair it with a strong and lasting place-making component.

Figure 13 presents the cumulative results, by Wrong and by criteria, for the nine case studies. The most frequent issues are all related with The Wrong Plan and The Wrong Budget: the top-down decision-making process that is often employed (Conceal, Dictate), to meet demanding deadlines and Olympic requirements, renders the projects susceptible to external influence (Interfere). Olympic interventions are typically very costly projects (Overspend), which may sometimes also grossly overrun estimates (Underestimate). Additionally, seeking iconic interventions often entails the inclusion of over dimensioned infrastructure and facilities (Overburden, Overengineer). The focus on organizing "the best Olympics ever" often leads to some neglect regarding post-event transformation (Improvise), which may hinder further investment and affect the image of the project (Deflate). At its worst, in a few cases, this led to incomplete implementation or abandonment of the plans (Unfinish).

Ensuring the economic viability of the Games can pressure decision-makers to pursue The Wrong Program, yielding to private interests in ensuring the short-term viability of the project (Sell-off), often not ensuring that the future reuse of the sites is one that promotes a vibrant mix of uses (Restrict). Furthermore, resorting to public funds for large infrastructure projects can disproportionately benefit developers (Capture). Many times, this imbalance is aggravated by social insensibility, as clearing the sites for the intervention requires evictions (Displace). Selecting large brownfield sites (Oversize) may limit this issue, but large urban 
voids are often only available in remote locations (Misplace). If good provision for public transit and appropriate site design are not ensured, this may lead to poorly connected sites (Isolate).

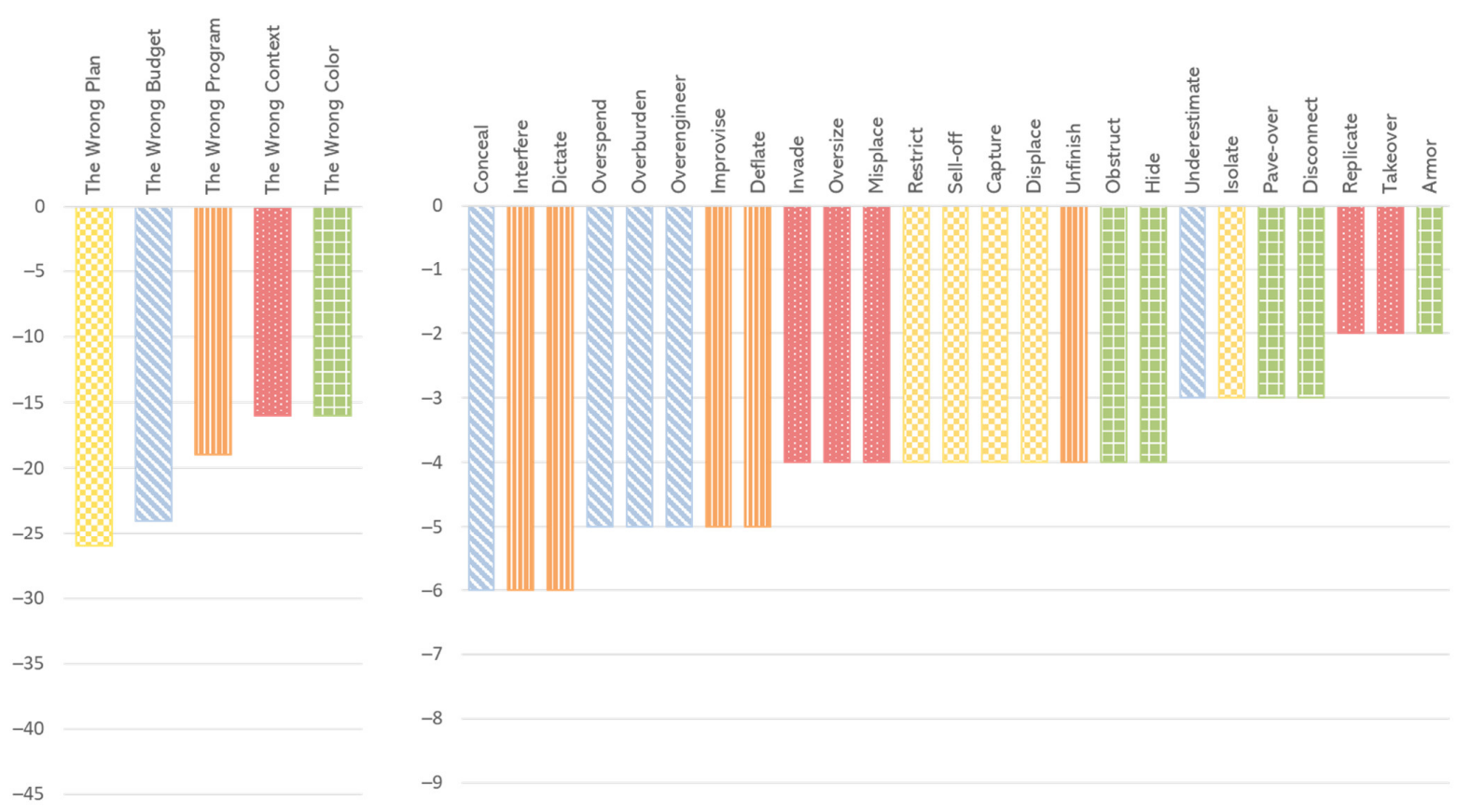

Figure 13. Cumulative results, by Wrong and by criteria, for the nine case studies. Own creation.

Among the least frequent is The Wrong Context. Given the visibility of Olympic projects, architects and urban planners are cautious in creating unique buildings and areas (do not Replicate) integrated within the waterfronts (no Takeover), even if sometimes disregarding local identity (Invade). Similarly infrequent is The Wrong Color, likely due to the public's growing awareness for environmental sustainability and evolving Olympic standards. Nevertheless, interventions still often Obstruct the longitudinal connectivity of waterbodies and fail to remediate, or even protect, wetland ecosystems (Hide), when there is the opportunity to do so. Some of the worst offenders go the extra mile and produce mostly impervious surfaces, with little provision for green areas, even altering or culverting creeks and wetlands (Pave-over). A few sites do not take advantage of the presence of water, failing to render the waterfront fully accessible and walkable (Disconnect). Even fewer interventions resulted in extensive new flood control features (Armor), but this may be explained by the frequent repurposing of sites that already had those hard defenses in place.

\section{Conclusions}

Our comparative evaluation of Olympic Waterfronts resorted to a modified version of the earlier "Fit of the Urban Waterfront Interventions" assessment tool [18], marking its first application to real-life case studies. The tool required adaptation to the much more specific nature of the uses and timeframes for implementation that are characteristic of Olympic sites, proving its flexibility and adaptability to different contexts. Each of the 25 criteria were revised and tested, and objective evaluation parameters were applied for each one of them. In its revised configuration, we were able to successfully apply it to assess positive and negative points for nine case studies, allowing to draw comparative assessments, indicate common issues, and identify best practices. We believe the methodology transparently addresses issues that affect waterfront redevelopment, while making it relevant also in highlighting frequent issues hindering post-event transformation of the sites. This theoretical framework can now be applied to other Olympic Waterfront interventions, with any further adaptations deemed necessary for specific contexts. 
While defining evaluation parameters, we decided to resort exclusively to existing literature for the evaluation of those criteria which could not be directly observed in maps and timelapse imagery. This was carried out so as to minimize subjective evaluation derived from the authors' inevitable personal biases. While reviews of one or more of the case studies have been produced (and are indeed used as reference works in our evaluation), ours is original in that it produces a systematic and comparative assessment of all Olympic Waterfront interventions since 1992, through a comparative evaluation of aspects that determine their quality. It allowed us to highlight common problems, and to pin-point other specific issues that, while not as common, may be at the root of some of the interventions' growing pains.

The simplified binary evaluation system is a necessary limitation, in favor of objectivity. There is no space, as is, to express the magnitude of failure: were all projects that received a certain negative $(-1)$ score equally bad? Certainly not. However, this simplification is necessary to ensure the ease of use, and that the methodology and its results can be easily explained and presented to decision-makers and the public, as it was designed to be. We tried to limit the level of subjectivity in each criteria's assessment, by resorting only to external sources for all those aspects that do not result from direct observation and attempting to obtain multiple sources for more controversial assessments. In any case, this preliminary research, as well as its results, could benefit from independent verification by native experts and/or residents of each site. Moreover, the proposed evaluation tool, when applied to new contexts, can, and indeed should, always be adjusted to the specificities of samples/case studies. Additionally, users can always implement scaling systems suiting their research and according to their specific needs-for example, multicriteria/multiparticipant evaluation. These exercises should equally be validated/tested with local stakeholders and experts.

One major potential for our revised methodology could come in its applications to other forms of major events-World Expos and other major sporting and cultural events. It now takes into consideration interesting aspects of legacy-planning and how to articulate time-delimited, high-demand events with a post-event "life" for the site, where inevitably the number of users at any given time will be much smaller, and the need to consider a diversity of uses often proves essential. We have arguably evolved some aspects of the earlier methodology, making the distinction between some of the criteria clearer while preserving the five Wrongs. We suggest that, even outside the context of mega-events, the methodology is now better suited for use in the broader context of waterfront regeneration, either for mega-projects or for smaller interventions. It can now be more readily explained, increasing its utility for its intended purpose: to serve as a tool to highlight issues that deserve further attention when deciding waterfront intervention projects and to reveal aspects that are often neglected as potential pressure points. These, if not addressed adequately, could hinder the waterfront's full potential for economic, social and ecological regeneration.

In the context of the Olympic Games, our results have highlighted how they are perceived as an opportunity to redevelop, reposition, or rebrand the host city. However, successful Games have not necessarily resulted in successful urban waterfront interventions. The urban legacy, and specifically the post-event success of waterfront locations, appears to have been an afterthought in some case studies. To us, this is, evidently, a wasted opportunity. The need to create several venues with limited potential for reuse after the event can limit the flexibility to adequately design the waterfront and reconnect it to the city. Significant changes to the plans during implementation can also compromise the outcome and coherence of the urban project.

The inflexible deadlines of the Olympics render the projects prone to cost overruns, and the responsibility for accommodating added expenses typically falls on the public sector. When made in a context of economic retraction, they can be used as a scapegoat for larger economic issues and can reinforce the image of "failed project" or "white elephant". This could hinder further steps in urban redevelopment of the sites. All urban redevel- 
opment projects have an inherent degree of unpredictability and sensitiveness to external factors. The Olympic Games add exponentially to this uncertainty, as significant changes to requirements are ubiquitous and can occur in virtually all stages of the Olympic cycle. Projects that were able to integrate Olympic Waterfronts in a broader strategy of urban redevelopment, and adequately planned for it, seem to have been more successful in creating attractive and cohesive urban projects, resulting in lasting legacies of the Olympic Games.

Increasingly, societal values have shifted towards a greater concern with the sustainability of large urban regeneration projects (social, economic, environmental). The Olympics have received criticism, by experts, activists, and the public, for being out of touch with current societal needs. As a consequence, the Olympic Agenda 2020 initiated a process of adjustment to growing concerns with the larger-than-life ambitions of some earlier interventions. This will directly impact the scope and nature of some projects, which are now expected to display a much greater concern for the sustainability of interventions, including its environmental and social responsibilities. However, early signs from coming events show that waterfront sites should continue to provide some of the most iconic locations for Olympic interventions. There is a future for the Olympic Waterfront.

Author Contributions: Conceptualization, P.J.P. and G.L.d.S.; methodology, P.J.P. and G.L.d.S.; formal analysis, P.J.P. and G.L.d.S.; investigation, P.J.P. and G.L.d.S.; writing—original draft preparation, P.J.P. and G.L.d.S.; writing—review and editing, P.J.P. and G.L.d.S.; visualization, P.J.P. and G.L.d.S. All authors have read and agreed to the published version of the manuscript.

Funding: Pedro Pinto was funded by the Portuguese Foundation for Science and Technology (FCT) Project MetroGov3C, Grant PTDC/GES-URB/30453/2017. This research is also within the scope of Gustavo Lopes dos Santos' PhD project "Sustainable Urban development and Mega-Events: The impacts of the Olympic Agenda 2020 in future Olympic Legacies", also supported by FCT, Grant SFRH/BD/146177/2019. Open access publication was financed through the authors' research center-CiTUA, IST-ID.

Institutional Review Board Statement: Not applicable.

Informed Consent Statement: Not applicable.

Data Availability Statement: Not applicable.

Conflicts of Interest: The authors declare no conflict of interest. The funders had no role in the design of the study; in the collection, analyses, or interpretation of data; in the writing of the manuscript, or in the decision to publish the results.

\section{Appendix A Criteria Definition}

Tables A1-A5 present the detailed definition and description of the criteria used for the assessment of waterfront projects, by Wrongs, as well as the limitations found during their implementation to Olympic waterfront case studies.

Table A1. Criteria for The Wrong Context: lack of attention to the local specificities.

\begin{tabular}{lll}
\hline \multicolumn{1}{c}{ Criteria } & \multicolumn{1}{c}{ Detailed Description } & \multicolumn{1}{c}{ Limitations } \\
\hline $\begin{array}{l}\text { Replicate: "copycat" } \\
\text { interventions, recreating } \\
\text { what was deemed as } \\
\text { successful elsewhere. }\end{array}$ & $\begin{array}{l}\text { Issues with lack of originality or a } \\
\text { reliance on models imported from } \\
\text { other projects. }\end{array}$ & $\begin{array}{l}\text { Most Olympic Waterfronts set out to create unique } \\
\text { legacies with distinct images, being perhaps less prone } \\
\text { than other "regular" waterfront interventions to rely } \\
\text { heavily on models or design solutions that were } \\
\text { successful elsewhere. }\end{array}$ \\
\hline $\begin{array}{l}\text { Invade: no regard for } \\
\text { local identity. }\end{array}$ & $\begin{array}{l}\text { Urban design and architecture do not } \\
\text { adequately consider issues such as } \\
\text { urban insertion or the local } \\
\text { architectural culture. }\end{array}$ & $\begin{array}{l}\text { Olympic projects may be somewhat expected to include } \\
\text { iconic buildings or a certain type of "grandiose" urban } \\
\text { layout, which may not facilitate integration within } \\
\text { existing urban fabric. }\end{array}$ \\
\hline
\end{tabular}


Table A1. Cont.

\begin{tabular}{lll}
\hline \multicolumn{1}{c}{ Criteria } & \multicolumn{1}{c}{ Detailed Description } & \multicolumn{1}{c}{ Limitations } \\
\hline $\begin{array}{l}\text { Takeover: no adaptation to } \\
\text { the existing morphology } \\
\text { and topography. }\end{array}$ & $\begin{array}{l}\text { Projects that failed to work/respect } \\
\text { existing banks and, instead, resorted to } \\
\text { the creation of artificial landfill and } \\
\text { water courses. }\end{array}$ & $\begin{array}{l}\text { Unlike other waterfront projects, most of the sites did } \\
\text { not require extensive topographic manipulation. }\end{array}$ \\
\hline $\begin{array}{l}\text { Oversize: projects too big } \\
\text { for the city size, program, or } \\
\text { local needs. }\end{array}$ & $\begin{array}{l}\text { Sites, buildings, or infrastructures } \\
\text { inadequate in size to the city's needs, } \\
\text { often resulting in underutilization and } \\
\text { unsustainability (see also Overburden). }\end{array}$ & $\begin{array}{l}\text { Due to the massive demand for sports infrastructure } \\
\text { and people flows over a very limited span of time, most } \\
\text { Olympic Waterfronts suffer to a degree of oversizing. } \\
\text { issue proved problematic. }\end{array}$ \\
\hline $\begin{array}{l}\text { Misplace: interventions } \\
\text { poorly located or } \\
\text { disconnected from } \\
\text { consolidated areas. }\end{array}$ & $\begin{array}{l}\text { Olympic Waterfronts placed in remote } \\
\text { or not easily accessible locations. }\end{array}$ & $\begin{array}{l}\text { Given its demanding requirements, Olympic projects } \\
\text { involve large land consumption. These large plots are } \\
\text { often only available for development in less accessible or } \\
\text { more remote locations. }\end{array}$ \\
\hline
\end{tabular}

Table A2. Criteria for The Wrong Budget: inaccurate assessment of cost-benefit.

Criteria Detailed Description

Underestimate: large cost overruns due to flawed budgets.
Overspend: projects too costly for their purpose.
Overburden: underutilized and not self-sustaining spaces, facilities or infrastructures.
Overengineer: large-scale expensive engineering with low cost-benefit.
Underestimation is considered when direct cost-overruns are higher than the average cost-overruns for all Olympic projects.
Overspending is considered when total direct costs are higher than the average costs for all Olympic projects.
Sites or venues with

high-maintenance costs and low utilization, often a consequence of too large (see Oversize) or incomplete projects (see Unfinish).
Building "bolder and stronger", even when more rational, site adequate, and sustainable alternatives were available. Applicable to public transit, roadways, bridges, canals, dams, etc.

\section{Limitations}

All Olympic projects present cost-overruns. The source used is a reference study for Olympic costs but regards only direct costs. Many budget components of Olympic Waterfronts usually fall under indirect costs.

Furthermore, the source does not allow the isolation of Olympic Waterfronts costs from the total direct costs for all Olympic sites.

The source used is a reference study for Olympic costs, but it regards only direct costs. Many budget components of Olympic Waterfronts usually fall under indirect costs. Furthermore, the source does not allow the isolation of Olympic Waterfronts costs from the total direct costs for all Olympic sites.

Being a highly subjective matter, it is difficult to adopt a unified criterion for underutilization or to evaluate maintenance costs. As such, evaluation is based on the existence of credible and comparable sources, in reference to the specific sites under analysis and not in reference to individual facilities/infrastructures.

If the project is not well suited for the site's morphology (Takeover) and/or location of the site is not ideal (Misplace), engineering and consequent costs can easily escalate. Infrastructure required for the Olympics may be over-dimensioned for daily needs, but while some may be outright unnecessary, others could simply require an adjustment.

No public accounting/accountability of spending which, given the huge investments involved, should be ensured through robust auditing and transparent procedures.
All Olympic projects have a certain degree of confidentiality, not only due to the large budgets and strict timelines, but also due to the intense mediatic exposure. 
Table A3. Criteria for The Wrong Program: short-sighted interventions targeted at niche segments.

Criteria Detailed Description

Diversity of land uses and public

Restrict: single-purpose areas, failing to attract diverse publics. spaces is highlighted as a fundamental aspect in promoting vitality in an urban environment. Monotonous zones often fail to attract diverse crowds at different times of the day/week/year.

\section{Sell-off: lacking} redundancy; exposing the project to demand fluctuations: if market stalls, nothing gets done.
Diversity of planned uses is frequently described as a way of increasing projects' resilience in face of market fluctuations. Criticisms of the project due to its inability to spur development are considered signs that diversity was not adequate.
Whenever a project presupposes shared investments between public and private entities, there should be a fair allocation of costs and benefits. Sometimes private developers are able to take excessive advantage of large public investment without adequate compensation.

\section{Limitations}

The creation of urban spaces with extreme concentration of sports facilities lends itself to a specialized function, catering to a very specific sector of the population. Therefore, the ability to integrate these facilities in diverse and well-designed public spaces could, but often does not, mitigate the "restrictive" nature of these spaces. Given this specific context-the creation of Olympic sites-a single-purpose area does not necessarily equate to an unattractive one.

This problem may be more evident whenever the site includes residential use or office space, as these land uses often presuppose post-event absorption by the real estate market. Whether they are Olympic Villages, large media centers, or locations with several sports facilities, it is frequent to find sites where the single-use nature (Restrict) may also hinder post-event investment in a saturated marketplace.

The Olympic projects typically include very large public investment for facilities and infrastructures that are not attractive for the private sector. Nevertheless, there is often ample opportunity to integrate the private sector in direct financing or even real-estate development that can contribute to offset part of the investment in betterments. However, it is difficult to effectively evaluate what is considered adequate cost-sharing, especially when those betterments are vital for the event itself.

Accessibility and mobility are fundamental to ensure a good delivery of the Olympics, but also to guarantee successful, functional and lasting urban legacies. Associated with the selection of remote locations (Misplace) comes the need to reinforce accessibility and mobility systems. mobility, connectivity, and transport to and from the area; deficient soft mobility/walkability.

\section{Displace:}

eviction/removal of local communities without proper compensation.
Land expropriation and/or eviction of communities. These can be done with or without a social consciousness and ensuring social rights are respected.
Serving remote locations with heavy transport peak demand.

The level of social awareness to issues such as housing rights and public participation vary considerably from country to country. Issues of displacement may be heavily scrutinized in one context, while systematic evictions may go largely unnoticed and underreported in others. infrastructure may prove difficult due to limited/

Table A4. Criteria for The Wrong Plan: bad project management.

\begin{tabular}{lll}
\hline \multicolumn{1}{c}{ Criteria } & \multicolumn{1}{c}{ Detailed Description } & \multicolumn{1}{c}{ Limitations } \\
\hline $\begin{array}{l}\text { Interfere: external interests } \\
\text { negatively affected the } \\
\text { waterfront intervention. }\end{array}$ & $\begin{array}{l}\text { Interventions subject to forced adjustments to } \\
\text { their original project, which may affect their } \\
\text { coherence, sometimes resulting from broader } \\
\text { regional/national interests. }\end{array}$ & $\begin{array}{l}\text { It is often difficult to isolate external interferences from normal } \\
\text { adaptations/revisions to original plans. Additionally, Olympic } \\
\text { projects often influence urban interventions that otherwise } \\
\text { would not engage in developing certain type of } \\
\text { facilities/infrastructure (especially for sports). }\end{array}$ \\
\hline $\begin{array}{l}\text { Unfinish: incomplete } \\
\text { delivery of projects. }\end{array}$ & $\begin{array}{l}\text { Tight schedules of Olympics can undo original } \\
\text { planning, leading to last minute adaptations, } \\
\text { elimination of some features, or incomplete } \\
\text { post-event adaptation. }\end{array}$ & $\begin{array}{l}\text { The planning for the Olympic Games is frequently subject to } \\
\text { lamlessly transition the public spaces and facilities post-event. } \\
\text { sdditionally, economic cycles may also hinder this process. As } \\
\text { such, the reasons for unfinished sites may not always }\end{array}$ \\
\hline
\end{tabular}


Table A4. Cont.

\begin{tabular}{|c|c|c|}
\hline Criteria & Detailed Description & Limitations \\
\hline $\begin{array}{l}\text { Improvise: absent/late } \\
\text { strategies on how to } \\
\text { guarantee post-event } \\
\text { operation/maintenance. }\end{array}$ & $\begin{array}{l}\text { A robust strategy on how to transfer } \\
\text { ownership/exploration to the final receiving } \\
\text { entities and how to engage the private sector is } \\
\text { particularly important in the Olympic context } \\
\text { to ensure continued use and transition } \\
\text { post-event. Last-minute improvisation or } \\
\text { limited resilience in face of unexpected events } \\
\text { may impair the process. }\end{array}$ & $\begin{array}{l}\text { Introducing a large number of sports facilities, office buildings } \\
\text { and housing units to the real-estate market over a short period } \\
\text { of time may lead to saturation, waning interest from private } \\
\text { investors and render post-event operation vulnerable to } \\
\text { economic cycles. }\end{array}$ \\
\hline $\begin{array}{l}\text { Deflate: loss of the initial } \\
\text { impetus; image of "failure" } \\
\text { which hinders further } \\
\text { investment. }\end{array}$ & $\begin{array}{l}\text { When the momentum/potential of the public } \\
\text { spaces/facilities is lost in the aftermath of a } \\
\text { mega-event and/or an incomplete } \\
\text { intervention it may lead to abandonment and, } \\
\text { consequently, create an aura of failure that can } \\
\text { dissuade future investments. }\end{array}$ & $\begin{array}{l}\text { Post-event transition is often difficult and subject to } \\
\text { adaptations that may reveal problematic. The management of } \\
\text { such issues should be carried out in a way that minimizes the } \\
\text { impacts on stakeholders' expectations and on the image of the } \\
\text { project. Abandonment of parts of the project without a strong } \\
\text { communication strategy and clear mid/long-term goals may } \\
\text { compromise event legacies. }\end{array}$ \\
\hline $\begin{array}{l}\text { Dictate: lack of public } \\
\text { outreach and engagement } \\
\text { with the local population. }\end{array}$ & $\begin{array}{l}\text { Engaging the local communities from early on } \\
\text { in the planning process tends to reinforce } \\
\text { community support and better address local } \\
\text { needs, ideally resulting in committed and } \\
\text { invested local stakeholders. }\end{array}$ & $\begin{array}{l}\text { The Olympics are subject to fixed deadlines and intense media } \\
\text { coverage, which are met with a level of } \\
\text { confidentiality-especially during bid stages-that tends to } \\
\text { induce top-down decisions, constrain public outreach, and } \\
\text { limit the potential for an early onset of participated planning. }\end{array}$ \\
\hline
\end{tabular}

Table A5. Criteria for The Wrong Color: Selecting 'easy grey' over 'feasible green'.

\begin{tabular}{|c|c|c|}
\hline Criteria & Detailed Description & Limitations \\
\hline $\begin{array}{l}\text { Pave-Over: reduced } \\
\text { provision of green areas; } \\
\text { resorting mostly to } \\
\text { impervious surfaces. }\end{array}$ & $\begin{array}{l}\text { Hard surfaces take over most of the site, with } \\
\text { disregard for the integration of natural elements } \\
\text { and the provision of public green areas. }\end{array}$ & $\begin{array}{l}\text { Olympic Games require extensive areas for pedestrian } \\
\text { circulation, infrastructure and facilities. As such, in smaller } \\
\text { plots it may be difficult to incorporate extensive green areas. } \\
\text { The evaluation of this criterium also took into consideration } \\
\text { less space intensive green infrastructure, such as passive } \\
\text { detention, green roofs, or the integration of natural elements } \\
\text { with pedestrian circuits in the design of public spaces. }\end{array}$ \\
\hline $\begin{array}{l}\text { Obstruct: no integrated view } \\
\text { of natural connectivity of } \\
\text { water systems. }\end{array}$ & $\begin{array}{l}\text { Artificial structures block off, dam or disturb the } \\
\text { natural flow of water, impairing longitudinal } \\
\text { connectivity, including fish migration and } \\
\text { sediment transport. }\end{array}$ & $\begin{array}{l}\text { On several sites, the artificial flow control structures predate } \\
\text { the Olympic intervention. Therefore, situations where the } \\
\text { project itself did not introduce new obstacles were } \\
\text { disregarded in the evaluation of this criterium. }\end{array}$ \\
\hline $\begin{array}{l}\text { Armor: flood "defense" } \\
\text { through hard walls or levees; } \\
\text { new landfill. }\end{array}$ & $\begin{array}{l}\text { Instead of more natural flood management } \\
\text { solutions, the project resorts to hard surfaces and } \\
\text { heavy engineered artificial structures } \\
\text { (embankments, riprap, dikes, landfill, etc.) to } \\
\text { provide flood defense or increase the availability } \\
\text { of land. }\end{array}$ & $\begin{array}{l}\text { As in Obstruct, this criterium considered only projects where } \\
\text { actions expanded or introduced hard flood defense structures } \\
\text { when compared to the situation before the intervention. }\end{array}$ \\
\hline $\begin{array}{l}\text { Hide: failing to protect, } \\
\text { valorize and restore the } \\
\text { natural wetland ecosystems. }\end{array}$ & $\begin{array}{l}\text { The project fails to preserve natural } \\
\text { habitats/ecosystems, does not consider natural } \\
\text { floodplains and fluvial terraces, nor provides } \\
\text { floodplain restoration. }\end{array}$ & $\begin{array}{l}\text { This criterium applies only to areas where the preservation } \\
\text { and/or restoration of wetland ecosystems was possible. } \\
\text { These include shorelines such as beaches, mudflats, marshes } \\
\text { or the preservation of floodplains and riparian vegetation. }\end{array}$ \\
\hline $\begin{array}{l}\text { Disconnect: inability to allow } \\
\text { proper access to, and } \\
\text { circulation along, } \\
\text { the waterfront. }\end{array}$ & $\begin{array}{l}\text { No provision to make the waterfront accessible } \\
\text { and make it visible or to promote social } \\
\text { interaction with the natural environment. } \\
\text { Preservation or creation of barriers to social } \\
\text { connectivity of the waterbody, including bank } \\
\text { access, circulation along the banks/shores and, if } \\
\text { applicable, across it. }\end{array}$ & $\begin{array}{l}\text { There is a spectrum of opportunities to reconnect waterfronts } \\
\text { with the urban fabric, ranging from linear barrier removal, } \\
\text { establishing trails along the banks, or promoting direct free } \\
\text { interaction with the waterbody. This criterium identifies } \\
\text { actions that failed to seize opportunities to improve the social } \\
\text { connectivity of the waterfront. }\end{array}$ \\
\hline
\end{tabular}

\section{Appendix B Assessment of Case Studies}

Table A6 very briefly describes the assessment of each criterion for all case studies, presenting the respective justification and source (if applicable). Evaluation methods for each of the criteria are also highlighted. 
Table A6. Detailed Olympic Waterfronts assessment, by criteria.

\begin{tabular}{|c|c|c|c|c|c|c|c|c|c|}
\hline $\begin{array}{c}\text { Criteria } \\
\text { Evaluation } \\
\text { Method(s) }\end{array}$ & Parc de Mar & $\begin{array}{c}\text { Sydney } \\
\text { Olympic Park }\end{array}$ & $\begin{array}{l}\text { Faliro Coastal Zone } \\
\text { OC }\end{array}$ & Hellinikon OC & $\begin{array}{l}\text { Olympic Green \& } \\
\text { Forest Park }\end{array}$ & $\begin{array}{l}\text { Vancouver Olympic } \\
\text { Village }\end{array}$ & $\begin{array}{l}\text { Queen Elizabeth } \\
\text { Olympic Park }\end{array}$ & Sochi Olympic Park & Barra Olympic Park \\
\hline $\begin{array}{c}\text { Replicate } \\
\text { Literature, Media, } \\
\text { Virtual site survey }\end{array}$ & $\begin{array}{l}\text { Often praised for its } \\
\text { architecture. The } \\
\text { urban intervention } \\
\text { set a standard for } \\
\text { waterfronts } \\
{[8,19,85,86] \text {. }}\end{array}$ & $\begin{array}{l}\text { Exemplary in regard } \\
\text { to sustainable } \\
\text { urbanism and } \\
\text { environmental } \\
\text { remediation [24] } \\
\text { (p. 1632). }\end{array}$ & $\begin{array}{l}\text { Architecture praised } \\
\text { and original plan by } \\
\text { Renzo Piano } \\
\text { well-received, } \\
\text { although } \\
\text { incomplete [30]. }\end{array}$ & $\begin{array}{l}\text { Lack of originality } \\
\text { has not been a major } \\
\text { criticism [33] (p. 42). }\end{array}$ & $\begin{array}{l}\text { Took hints from } \\
\text { Sydney and other } \\
\text { host cities, but with } \\
\text { a unique and } \\
\text { well-received } \\
\text { design [40]. }\end{array}$ & $\begin{array}{l}\text { Exemplary design in } \\
\text { sustainable } \\
\text { architecture and } \\
\text { urbanism [ }[87] .\end{array}$ & $\begin{array}{l}\text { Learned from past } \\
\text { events to create a } \\
\text { long-term } \\
\text { regeneration } \\
\text { deemed unique and } \\
\text { successful [55]. }\end{array}$ & $\begin{array}{l}\text { Some venues } \\
\text { characterized as } \\
\text { unoriginal or as } \\
\text { attempts to emulate } \\
\text { other projects and } \\
\text { eras [61]. }\end{array}$ & $\begin{array}{l}\text { Masterplan } \\
\text { interesting for local } \\
\text { urbanism; } \\
\text { compromised by } \\
\text { developer pressure } \\
\text { [76] (p. 695). }\end{array}$ \\
\hline $\begin{array}{c}\text { Invade } \\
\text { Literature, Media }\end{array}$ & $\begin{array}{l}\text { Urban expansion } \\
\text { towards the } \\
\text { waterfront, } \\
\text { surpassing a } \\
\text { boundary imposed } \\
\text { by a railway line [8] } \\
\text { (p. 1332). } \\
\end{array}$ & $\begin{array}{l}\text { Park detached from } \\
\text { other areas } \\
\text { (although the village } \\
\text { was well } \\
\text { integrated) [21]. }\end{array}$ & $\begin{array}{l}\text { Occupation of } \\
\text { landfills adjacent to } \\
\text { a dense urban area, } \\
\text { providing a renewed } \\
\text { waterfront for } \\
\text { central Athens [27]. }\end{array}$ & $\begin{array}{l}\text { Reuse of abandoned } \\
\text { plot with no } \\
\text { provisions to } \\
\text { implement forest } \\
\text { park and integrate in } \\
\text { existing fabric [33] } \\
\text { (pp. 38-43). }\end{array}$ & $\begin{array}{l}\text { Radical intervention } \\
\text { yet integrated in } \\
\text { existing } \\
\text { urbanization and } \\
\text { providing much } \\
\text { needed green } \\
\text { spaces [40,46]. }\end{array}$ & $\begin{array}{l}\text { Occupation of an } \\
\text { empty plot adjacent } \\
\text { to a dense urban } \\
\text { area, promoting } \\
\text { brownfield } \\
\text { regeneration [48]. }\end{array}$ & $\begin{array}{l}\text { Hard limits } \\
\text { surpassed through } \\
\text { aerial crossings, } \\
\text { softly layering } \\
\text { expansion to green } \\
\text { areas and } \\
\text { waterfront [55]. } \\
\end{array}$ & $\begin{array}{l}\text { Place appropriation, } \\
\text { transfiguring local } \\
\text { appearance and } \\
\text { detached from the } \\
\text { existing urban } \\
\text { fabric [62] (p. 1), [65]. }\end{array}$ & $\begin{array}{l}\text { Not inclusive } \\
\text { villages lacking } \\
\text { integration with } \\
\text { existing } \\
\text { neighborhoods and } \\
\text { local identity [68], } \\
\text { [76] (p. 695), [78]. }\end{array}$ \\
\hline $\begin{array}{c}\text { Takeover } \\
\text { Time-lapse imagery } \\
\text { analysis }\end{array}$ & $\begin{array}{l}\text { The highly modified } \\
\text { shoreline predated } \\
\text { the Olympic } \\
\text { interventions. } \\
\text { Limited landfilling. }\end{array}$ & $\begin{array}{l}\text { Public parks system } \\
\text { protected valuable } \\
\text { mangrove, } \\
\text { shorelines and forest } \\
\text { ecosystems. }\end{array}$ & $\begin{array}{l}\text { Additional landfill } \\
\text { and extensively } \\
\text { remodeling of } \\
\text { shoreline; } \\
\text { subsidence } \\
\text { experienced [88]. }\end{array}$ & $\begin{array}{l}\text { Limited impact over } \\
\text { the existing Agios } \\
\text { Kosmas shoreline. }\end{array}$ & $\begin{array}{l}\text { Creation of an } \\
\text { extensive } \\
\text { "reconstructed" river } \\
\text { and wetland system; } \\
\text { extensive } \\
\text { terraforming. }\end{array}$ & $\begin{array}{l}\text { Original shoreline } \\
\text { mostly preserved } \\
\text { and local beach } \\
\text { habitat restored. }\end{array}$ & $\begin{array}{l}\text { Limited remodeling } \\
\text { of the river valley for } \\
\text { parks and habitat } \\
\text { restoration; natural } \\
\text { values preserved. }\end{array}$ & $\begin{array}{l}\text { Existing shoreline } \\
\text { mostly preserved, if } \\
\text { reinforced with } \\
\text { shoreline protection. }\end{array}$ & $\begin{array}{l}\text { Existing, already } \\
\text { heavily modified, } \\
\text { shoreline preserved. }\end{array}$ \\
\hline $\begin{array}{c}\text { Oversize } \\
\text { Literature, Media }\end{array}$ & $\begin{array}{l}\text { Needed } \\
\text { infrastructures and } \\
\text { rehabilitation of the } \\
\text { waterfront [8] } \\
\text { (p. 1332), proving } \\
\text { valuable to the } \\
\text { city [9]. }\end{array}$ & $\begin{array}{l}\text { Empty public space } \\
\text { with too big and } \\
\text { spread-out facilities. } \\
\text { "The scale of the } \\
\text { place is the enemy of } \\
\text { place making" [21]. }\end{array}$ & $\begin{array}{l}\text { An intervention } \\
\text { needed and planned } \\
\text { for long to open the } \\
\text { waterfront to the } \\
\text { population [31] } \\
\text { (p. 198). }\end{array}$ & $\begin{array}{l}\text { Several venues for } \\
\text { sports not popular in } \\
\text { Greece; numerous } \\
\text { convention centers } \\
\text { exceeding city needs } \\
\text { [1] (pp. 324, 335) }\end{array}$ & $\begin{array}{l}\text { Urban design and } \\
\text { forest park address } \\
\text { needs of the larger } \\
\text { metropolitan area, } \\
\text { despite oversize of } \\
\text { the Stadium }[40,47] .\end{array}$ & $\begin{array}{l}\text { No evidence } \\
\text { regarding oversizing } \\
\text { of buildings or } \\
\text { public } \\
\text { space-walkable } \\
\text { distances [48]. }\end{array}$ & $\begin{array}{l}\text { Continuous growth } \\
\text { and a variety of uses } \\
\text { for local and visiting } \\
\text { populations, } \\
\text { addressing city } \\
\text { needs [53,55]. }\end{array}$ & $\begin{array}{l}\text { Empty except for } \\
\text { events. Oversized } \\
\text { venues, overlapping } \\
\text { functions. Low hotel } \\
\text { bookings [63] (pp. } \\
\text { 340-341,344). }\end{array}$ & $\begin{array}{l}\text { Empty/unused } \\
\text { space and venues, } \\
\text { lacking maintenance } \\
\text { Park closed for } \\
\text { security reasons. } \\
\text { Vacant lots }[74,79] .\end{array}$ \\
\hline $\begin{array}{c}\text { Misplace } \\
\text { Map analysis }\end{array}$ & $\begin{array}{l}\text { Central location, } \\
\text { well connected to } \\
\text { existing urban fabric } \\
\text { and accessible by } \\
\text { public transit. }\end{array}$ & $\begin{array}{l}\text { Park located in the } \\
\text { suburbs, requiring } \\
\text { costly transport } \\
\text { infrastructure and } \\
\text { affecting attractivity } \\
\text { for certain land uses. }\end{array}$ & $\begin{array}{l}\text { Located where } \\
\text { downtown reaches } \\
\text { the seashore, it is a } \\
\text { central and } \\
\text { well-connected } \\
\text { location. }\end{array}$ & $\begin{array}{l}\text { Former airport } \\
\text { readily available, but } \\
\text { access is limited; } \\
\text { barriers prevent easy } \\
\text { integration with } \\
\text { existing } \\
\text { fabric/seafront. }\end{array}$ & $\begin{array}{l}\text { Not centrally located } \\
\text { but planned as a } \\
\text { new centrality; now } \\
\text { well integrated with } \\
\text { consolidated city. }\end{array}$ & $\begin{array}{l}\text { Central location, } \\
\text { promoting the } \\
\text { regeneration of a } \\
\text { brownfield, well } \\
\text { integrated and well } \\
\text { connected. }\end{array}$ & $\begin{array}{l}\text { Core part of East } \\
\text { London regenerated, } \\
\text { creating a new } \\
\text { centrality and } \\
\text { promoting access } \\
\text { and } \\
\text { multifunctionality. }\end{array}$ & $\begin{array}{l}\text { Located about } 30 \mathrm{~km} \\
\text { from central Sochi; } \\
\text { limited public transit } \\
\text { connection. Not well } \\
\text { integrated with } \\
\text { surroundings. }\end{array}$ & $\begin{array}{l}\text { Difficult access from } \\
\text { central Rio. } \\
\text { Masterplan } \\
\text { attempted } \\
\text { integration with } \\
\text { older fabric, but new } \\
\text { allotment plan } \\
\text { did not. }\end{array}$ \\
\hline $\begin{array}{l}\text { Underestimate } \\
\text { Literature: [12] } \\
\quad \text { (p. 240) }\end{array}$ & $\begin{array}{l}\text { Barcelona } 1992- \\
\text { Cost overrun: } 266 \% \text {, } \\
53 \% \text { over average. }\end{array}$ & $\begin{array}{l}\text { Sydney } 2000-\text { Cost } \\
\text { overrun: } 90 \%, 123 \% \\
\text { below average. }\end{array}$ & \multicolumn{2}{|c|}{$\begin{array}{l}\text { Athens } 2004-\text { Cost overrun: } 49 \%, 164 \% \text { below } \\
\text { average. }\end{array}$} & $\begin{array}{l}\text { Beijing } 2008-\text { Cost } \\
\text { overrun: } 2 \%, 211 \% \\
\text { below average. }\end{array}$ & $\begin{array}{l}\text { Vancouver } 2010- \\
\text { Cost overrun: } 13 \% \text {, } \\
129 \% \text { below average. } \\
\text { Village overrun: } 13 \% \\
\text { [50] (p. 274). }\end{array}$ & $\begin{array}{l}\text { London } 2012-\text { Cost } \\
\text { overrun: } 76 \%, 137 \% \\
\text { below average. }\end{array}$ & $\begin{array}{l}\text { Sochi } 2014-\text { Cost } \\
\text { overrun: } 289 \%, 147 \% \\
\text { over average. }\end{array}$ & $\begin{array}{l}\text { Rio } 2016 \text {-Cost } \\
\text { overrun: } 352 \%, 139 \% \\
\text { over average. }\end{array}$ \\
\hline
\end{tabular}


Table A6. Cont.

\begin{tabular}{|c|c|c|c|c|c|c|c|c|c|}
\hline $\begin{array}{l}\text { Criteria } \\
\text { Evaluation } \\
\text { Method(s) }\end{array}$ & Parc de Mar & $\begin{array}{c}\text { Sydney } \\
\text { Olympic Park }\end{array}$ & $\begin{array}{l}\text { Faliro Coastal Zone } \\
\text { OC }\end{array}$ & Hellinikon OC & $\begin{array}{l}\text { Olympic Green \& } \\
\text { Forest Park }\end{array}$ & $\begin{array}{l}\text { Vancouver Olympic } \\
\text { Village }\end{array}$ & $\begin{array}{l}\text { Queen Elizabeth } \\
\text { Olympic Park }\end{array}$ & Sochi Olympic Park & Barra Olympic Park \\
\hline $\begin{array}{l}\text { Overspend } \\
\text { Literature: [12] } \\
\quad(p .236)\end{array}$ & $\begin{array}{l}\text { Barcelona 1992-- } \\
\text { Cost: USD 9.687 } \\
\text { billion, USD } 3.713 \\
\text { billion over average. }\end{array}$ & $\begin{array}{l}\text { Sydney 2000-Cost: } \\
\text { USD } 5.026 \text { billion, } \\
\text { USD } 0.948 \text { billion } \\
\text { below average. }\end{array}$ & \multicolumn{2}{|c|}{$\begin{array}{l}\text { Athens } 2004-\text { Cost: USD } 2.942 \text { billion, USD } \\
3.032 \text { billion below average. }\end{array}$} & $\begin{array}{l}\text { Beijing 2008-Cost: } \\
\text { USD } 6.810 \text { billion, } \\
\text { USD } 0.836 \text { billion } \\
\text { over average. }\end{array}$ & $\begin{array}{l}\text { Vancouver 2010- } \\
\text { Cost: USD 2.540 } \\
\text { billion, USD } 0.572 \\
\text { billion below } \\
\text { average. Village cost: } \\
\text { USD 1.075 billion } \\
\text { [50] (p. 274). }\end{array}$ & $\begin{array}{l}\text { London 2012-Cost: } \\
\text { USD } 14.957 \text { billion, } \\
\text { USD } 8.983 \text { billion } \\
\text { over average. }\end{array}$ & $\begin{array}{l}\text { Sochi 2014-Cost: } \\
\text { USD } 21.890 \text { billion, } \\
\text { USD } 18.778 \text { billion } \\
\text { over average. }\end{array}$ & $\begin{array}{l}\text { Rio } 2016 \text {-Cost: } \\
\text { USD } 13.692 \text { billion, } \\
\text { USD } 7.718 \text { billion } \\
\text { over average. }\end{array}$ \\
\hline $\begin{array}{l}\text { Overburden } \\
\text { Literature, Media }\end{array}$ & $\begin{array}{l}\text { Opened an obsolete/ } \\
\text { marginal area to } \\
\text { public use } \\
\text { (nowadays vibrant) } \\
\text { [8] (p. 1332), [9]. }\end{array}$ & $\begin{array}{l}\text { The Olympic Park is } \\
\text { the Games' white } \\
\text { elephant and unused } \\
\text { outside large events } \\
\text { [21]. }\end{array}$ & $\begin{array}{l}\text { Abandoned/locked } \\
\text { facilities [36,37]. } \\
\text { Maintenance costing } \\
\text { EUR 5-7 million vs. } \\
\text { revenues of EUR 2-4 } \\
\text { million [1] (pp. 331, } \\
\text { 333). }\end{array}$ & $\begin{array}{l}\text { Abandoned/damaged } \\
\text { (now a refugee } \\
\text { camp) [89] (pp.3). } \\
\text { Not self-sustaining } \\
\text { [1] (p. 51), [36,37]. }\end{array}$ & $\begin{array}{l}\text { Used venues, at least } \\
\text { occasionally, but } \\
\text { high-maintenance } \\
\text { costs (Stadium, } \\
\text { especially) [44]. }\end{array}$ & $\begin{array}{l}\text { Vibrant } \\
\text { neighborhood with } \\
\text { satisfactory livability } \\
\text { [48]. }\end{array}$ & $\begin{array}{l}\text { Stadium struggled to } \\
\text { find a purpose, but } \\
\text { venues/infrastructure } \\
\text { proved } \\
\text { self-sustainable [53]. }\end{array}$ & $\begin{array}{l}\text { No evidence found } \\
\text { for not } \\
\text { self-sustainability of } \\
\text { venues. }\end{array}$ & $\begin{array}{l}\text { In 2017, the } \\
\text { operation of the } \\
\text { Olympic Park paid } \\
\text { only for } 2 \% \text { of its } \\
\text { maintenance } \\
\text { costs [74]. }\end{array}$ \\
\hline $\begin{array}{c}\text { Overengineer } \\
\text { Literature, Media }\end{array}$ & $\begin{array}{l}\text { Heavy investment } \\
\text { on transport and } \\
\text { flood defense } \\
\text { infrastructure but } \\
\text { aligned with local } \\
\text { and regional } \\
\text { needs [90]. }\end{array}$ & $\begin{array}{l}\text { New railway line } \\
\text { not bringing people } \\
\text { in on a regular } \\
\text { basis [21]. }\end{array}$ & $\begin{array}{l}\text { Heavy transport } \\
\text { infrastructure, } \\
\text { including aerial and } \\
\text { underground } \\
\text { crossings, flood } \\
\text { defense and } \\
\text { landfill [28]. }\end{array}$ & $\begin{array}{l}\text { A quick fix without } \\
\text { major/expensive } \\
\text { interventions, except } \\
\text { for the Agios } \\
\text { Kosmas port. }\end{array}$ & $\begin{array}{l}\text { Artificial landscape } \\
\text { and very large } \\
\text { venues. Some not } \\
\text { self-sustainable } \\
\text { "eco-friendly" } \\
\text { solutions [43]. }\end{array}$ & $\begin{array}{l}\text { High-tech solutions } \\
\text { resulting in } \\
\text { significant } \\
\text { maintenance and } \\
\text { operation difficulties } \\
\text { [48]. }\end{array}$ & $\begin{array}{l}\text { Although heavy, } \\
\text { transport } \\
\text { infrastructure } \\
\text { proved needed and } \\
\text { flood defense } \\
\text { already existed. }\end{array}$ & $\begin{array}{l}\text { Highly over } \\
\text { dimensioned roads. } \\
\text { Railway and train } \\
\text { station receive } \\
\text { limited service [63] } \\
\text { (p. 341), [64] (p. 218). }\end{array}$ & $\begin{array}{l}\text { The BRT was } \\
\text { relatively } \\
\text { inexpensive, with } \\
\text { current demand } \\
\text { justifying needs [69] } \\
\text { (p. 21), [70]. }\end{array}$ \\
\hline $\begin{array}{c}\text { Conceal } \\
\text { Literature, Media }\end{array}$ & $\begin{array}{l}\text { Compliance with } \\
\text { pre-established } \\
\text { regulations [8] } \\
\text { (p. 1332). }\end{array}$ & $\begin{array}{l}\text { No evidence found } \\
\text { for lack of } \\
\text { transparency in } \\
\text { regard to the project. }\end{array}$ & \multicolumn{2}{|c|}{$\begin{array}{l}\text { Real costs never clearly disclosed under the } \\
\text { justification that many interventions were not } \\
\text { Games' contractual obligations. Political } \\
\text { parties and media demanded audits [91]. }\end{array}$} & $\begin{array}{l}\text { Limited role of } \\
\text { public/media or } \\
\text { political parties in } \\
\text { regard to freedom of } \\
\text { expression [45] } \\
\text { (p. 168). }\end{array}$ & $\begin{array}{l}\text { Project deemed } \\
\text { unviable. } \\
\text { Information } \\
\text { withheld; decisions } \\
\text { lacking clarity [51] } \\
\text { (pp. 66-67). }\end{array}$ & $\begin{array}{l}\text { No evidence found } \\
\text { for lack of } \\
\text { transparency in } \\
\text { regard to the project. }\end{array}$ & $\begin{array}{l}\text { Construction } \\
\text { without legal } \\
\text { paperwork, political } \\
\text { corruption and lack } \\
\text { of transparency [64] } \\
\text { (p. 215). }\end{array}$ & $\begin{array}{l}\text { Cases of corruption } \\
\text { linked to } \\
\text { constructions and } \\
\text { post-event changes } \\
\text { to the masterplan } \\
{[73,76] \text {. }}\end{array}$ \\
\hline $\begin{array}{c}\text { Restrict } \\
\text { Literature, Media }\end{array}$ & $\begin{array}{l}\text { Waterfront } \\
\text { intervention } \\
\text { promoted access and } \\
\text { mixed-use; new and } \\
\text { vibrant urban } \\
\text { district [19]. }\end{array}$ & $\begin{array}{l}\text { Project criticized for } \\
\text { creating large } \\
\text { monofunctional } \\
\text { zones [25]. }\end{array}$ & $\begin{array}{l}\text { Unfinished; but will } \\
\text { create a new } \\
\text { waterfront centrality, } \\
\text { with parks, sports } \\
\text { and culture facilities } \\
\text { [26]. }\end{array}$ & $\begin{array}{l}\text { Empty; } \\
\text { transformation into } \\
\text { a large forest park } \\
\text { never formalized } \\
\text { [33] (p. 42). }\end{array}$ & $\begin{array}{l}\text { Created a new } \\
\text { centrality in the city } \\
\text { and addressed the } \\
\text { lack of a major large } \\
\text { forest park [40]. }\end{array}$ & $\begin{array}{l}\text { Created a mixed-use, } \\
\text { sustainable } \\
\text { neighborhood with } \\
\text { good accessibility } \\
\text { [48]. }\end{array}$ & $\begin{array}{l}\text { New centrality, } \\
\text { anchored in a large } \\
\text { park. Diverse uses } \\
\text { and great pedestrian } \\
\text { network [53]. }\end{array}$ & $\begin{array}{l}\text { Relatively successful } \\
\text { event venue [67]; } \\
\text { failed to create } \\
\text { diverse, walkable } \\
\text { and mixed-use } \\
\text { area [62]. }\end{array}$ & $\begin{array}{l}\text { Village converted to } \\
\text { condominiums. } \\
\text { Masterplan changed } \\
\text { to offer upper-class } \\
\text { high-rises }[68,78] .\end{array}$ \\
\hline $\begin{array}{c}\text { Sell-off } \\
\text { Literature, Media }\end{array}$ & $\begin{array}{l}\text { Long-term success of } \\
\text { the mixed-use } \\
\text { development, often } \\
\text { named as a } \\
\text { model [19]. }\end{array}$ & $\begin{array}{l}\text { Together, the } \\
\text { different } \\
\text { monofunctional } \\
\text { zones provide } \\
\text { diverse uses, most of } \\
\text { them successful [25]. }\end{array}$ & $\begin{array}{l}\text { Planned post-event } \\
\text { transformation } \\
\text { delayed but } \\
\text { including diverse } \\
\text { uses. A few are only } \\
\text { now being } \\
\text { developed [26]. }\end{array}$ & $\begin{array}{l}\text { As is, the site is } \\
\text { monofunctional and } \\
\text { abandoned. Plans to } \\
\text { transform it to a Park } \\
\text { not finalized [33]. }\end{array}$ & $\begin{array}{l}\text { Vibrant } \\
\text { multifunctional } \\
\text { centrality and a } \\
\text { sorely needed large } \\
\text { forest park [40]. }\end{array}$ & $\begin{array}{l}\text { Planned social mix, } \\
\text { with expensive } \\
\text { social housing, } \\
\text { vulnerable to market } \\
\text { fluctuations } \\
\text { (required } \\
\text { revisions) [51]. }\end{array}$ & $\begin{array}{l}\text { Includes mixed-use } \\
\text { development, sports } \\
\text { venues already } \\
\text { needed and a large } \\
\text { park serving as a } \\
\text { new centrality [55]. }\end{array}$ & $\begin{array}{l}\text { Offer of many event } \\
\text { venues, some } \\
\text { blatantly privatized, } \\
\text { but little in the way } \\
\text { of day-to-day } \\
\text { city-building } \\
\text { [59,62,64]. }\end{array}$ & $\begin{array}{l}\text { Masterplan } \\
\text { subverted to allow } \\
\text { "business as usual" } \\
\text { in real-estate, } \\
\text { targeted at the } \\
\text { upper-class } \\
\text { market [68,78]. }\end{array}$ \\
\hline
\end{tabular}


Table A6. Cont.

\begin{tabular}{|c|c|c|c|c|c|c|c|c|c|}
\hline $\begin{array}{c}\text { Criteria } \\
\text { Evaluation } \\
\text { Method(s) }\end{array}$ & Parc de Mar & $\begin{array}{c}\text { Sydney } \\
\text { Olympic Park }\end{array}$ & $\begin{array}{l}\text { Faliro Coastal Zone } \\
\text { OC }\end{array}$ & Hellinikon OC & $\begin{array}{l}\text { Olympic Green \& } \\
\text { Forest Park }\end{array}$ & $\begin{array}{c}\text { Vancouver Olympic } \\
\text { Village }\end{array}$ & $\begin{array}{l}\text { Queen Elizabeth } \\
\text { Olympic Park }\end{array}$ & Sochi Olympic Park & Barra Olympic Park \\
\hline $\begin{array}{c}\text { Capture } \\
\text { Literature, Media }\end{array}$ & $\begin{array}{l}\text { While costly, the } \\
\text { projected to } \\
\text { regenerate the city's } \\
\text { waterfront through } \\
\text { mostly public } \\
\text { investment [8] } \\
\text { (p. 1332). }\end{array}$ & $\begin{array}{l}\text { The project included } \\
\text { several PPP, which } \\
\text { have worked } \\
\text { relatively well } \\
{[52,92,93] \text {. }}\end{array}$ & $\begin{array}{l}\text { Originally intended } \\
\text { as a PPP, investment } \\
\text { ended up being } \\
\text { mostly public-but } \\
\text { so were the uses [45] } \\
\text { (p. 697), [94]. }\end{array}$ & $\begin{array}{l}\text { External pressures } \\
\text { forced a } \\
\text { progressively larger } \\
\text { privatization of } \\
\text { plans for the forest } \\
\text { park [27], [33] (p. 42). }\end{array}$ & $\begin{array}{l}\text { Larger share of } \\
\text { investment was } \\
\text { public, but resorted } \\
\text { to PPP where viable } \\
\text { (e.g., village and } \\
\text { stadium) [95,96]. }\end{array}$ & $\begin{array}{l}\text { Original cost-sharing } \\
\text { strategies affected by } \\
\text { economic crisis. } \\
\text { New solution less } \\
\text { beneficial to the } \\
\text { public }[48,51] .\end{array}$ & $\begin{array}{l}\text { Despite soaring } \\
\text { costs, the Legacy } \\
\text { Plan addressed } \\
\text { post-event } \\
\text { development and } \\
\text { cost-sharing [55]. }\end{array}$ & $\begin{array}{l}\text { Heavy public } \\
\text { investment criticized } \\
\text { for benefiting } \\
\text { disproportionately } \\
\text { the local elite } \\
{[59,62,64] \text {. }}\end{array}$ & $\begin{array}{l}\text { Post-event uses } \\
\text { criticized for } \\
\text { replicating } \\
\text { privatized real-estate } \\
\text { development typical } \\
\text { elsewhere in } \\
\text { Rio }[68,78] .\end{array}$ \\
\hline $\begin{array}{c}\text { Isolate } \\
\text { Literature, Media, } \\
\text { Analysis of transit } \\
\text { maps/schedules }\end{array}$ & $\begin{array}{l}\text { The waterfront is } \\
\text { highly walkable and } \\
\text { served by several } \\
\text { public transit } \\
\text { stations and stops. }\end{array}$ & $\begin{array}{l}\text { While } \\
\text { monofunctional } \\
\text { zones do not } \\
\text { encourage walking, } \\
\text { the area is served by } \\
\text { public transit. }\end{array}$ & $\begin{array}{l}\text { In its definitive form, } \\
\text { the site will be } \\
\text { accessible, served by } \\
\text { public transit and } \\
\text { will promote } \\
\text { connection to } \\
\text { the sea. }\end{array}$ & $\begin{array}{l}\text { The tram line serves } \\
\text { only the coastline. } \\
\text { Limited connection } \\
\text { between the } \\
\text { waterfront and the } \\
\text { abandoned site. }\end{array}$ & $\begin{array}{l}\text { Public transit, } \\
\text { including new metro } \\
\text { stations, serve the } \\
\text { neighborhood. }\end{array}$ & $\begin{array}{l}\text { Well-connected, } \\
\text { centrally located } \\
\text { neighborhood, } \\
\text { accessible through } \\
\text { public transit [48]. }\end{array}$ & $\begin{array}{l}\text { Accessible by } \\
\text { several public transit } \\
\text { hubs and is very } \\
\text { walkable [55]. }\end{array}$ & $\begin{array}{l}\text { Poor internal } \\
\text { walkability. Ample } \\
\text { access for motor } \\
\text { vehicles but served } \\
\text { by a marginal train } \\
\text { station (infrequent } \\
\text { service). }\end{array}$ & $\begin{array}{l}\text { Promises of a } \\
\text { well-connected } \\
\text { neighborhood } \\
\text { replaced by limited } \\
\text { and indirect } \\
\text { connection through } \\
\text { a BRT line [70]. }\end{array}$ \\
\hline $\begin{array}{c}\text { Displace } \\
\text { Literature, Media }\end{array}$ & $\begin{array}{l}\text { No forced evictions; } \\
\text { all residents } \\
\text { rehoused/ } \\
\text { compensated [45] } \\
\text { (p. 112). }\end{array}$ & $\begin{array}{l}\text { No forced evictions } \\
\text { (although other } \\
\text { negative housing } \\
\text { impacts occurred) } \\
\text { [45] (p. 126). }\end{array}$ & \multicolumn{2}{|c|}{$\begin{array}{l}\text { Athens } 2004 \text { triggered evictions of Romani } \\
\text { communities (mostly indirect) but not in the } \\
\text { case study sites [45] (pp. 142-153). }\end{array}$} & $\begin{array}{l}\text { Massive evictions; } \\
\text { only small } \\
\text { percentages } \\
\text { relocated or } \\
\text { compensated [45] } \\
\text { (pp. 165-166, 797). }\end{array}$ & $\begin{array}{l}\text { Few displacements } \\
\text { nearby the village } \\
\text { (Games-related but } \\
\text { not for construction) } \\
\text { [49] (p. 398). }\end{array}$ & $\begin{array}{l}450 \text { tenants evicted } \\
\text { and relocated } \\
\text { through compulsory } \\
\text { purchase (involving } \\
\text { contestations) [57]. }\end{array}$ & $\begin{array}{l}\text { Close to } 2000 \\
\text { families evicted. } \\
\text { Poor or inexistent } \\
\text { compensation [64] } \\
\text { (p. 210). }\end{array}$ & $\begin{array}{l}\text { Demolition of a } 4000 \\
\text { people settlement } \\
\text { with derisory } \\
\text { compensation [71] } \\
\text { (p. 1145). }\end{array}$ \\
\hline $\begin{array}{c}\text { Interfere } \\
\text { Literature, Media }\end{array}$ & $\begin{array}{l}\text { The Games were an } \\
\text { opportunity to } \\
\text { pursue city-wide } \\
\text { strategies and } \\
\text { planned } \\
\text { interventions [8] } \\
\text { (pp.1332). }\end{array}$ & $\begin{array}{l}\text { The Park was } \\
\text { designed for the } \\
\text { needs of the event } \\
\text { and not for the needs } \\
\text { of the city [21]. }\end{array}$ & \multicolumn{2}{|c|}{$\begin{array}{l}\text { Irresponsible bid, for celebratory reasons, not } \\
\text { in line with the economic situation. } \\
\text { Significant masterplan changes resulting from } \\
\text { team adjustments and rethinking the Games' } \\
\text { logistics. Subsequent plan on the basis of } \\
\text { public landownership and/or commercial } \\
\text { interests [1] (pp. 51,321), [33]. }\end{array}$} & $\begin{array}{l}\text { Although city- } \\
\text { branding-oriented, } \\
\text { the project also } \\
\text { fulfilled several } \\
\text { previously } \\
\text { diagnosed needs } \\
\text { [40]. }\end{array}$ & $\begin{array}{l}\text { Necessity to ensure } \\
\text { the Games' delivery } \\
\text { affected the } \\
\text { financing model and, } \\
\text { ultimately, the share } \\
\text { of affordable } \\
\text { housing [51] (pp.66). }\end{array}$ & $\begin{array}{l}\text { Early legacy } \\
\text { planning, clear } \\
\text { roadmap and vision. } \\
\text { For the most part, } \\
\text { successful without } \\
\text { much change [55]. }\end{array}$ & $\begin{array}{l}\text { Site redevelopment } \\
\text { driven by } \\
\text { commercial interests } \\
\text { and national } \\
\text { objectives, } \\
\text { inadequately } \\
\text { territorialized [62]. }\end{array}$ & $\begin{array}{l}\text { Corruption and } \\
\text { private interests } \\
\text { affected planning, } \\
\text { construction, legacy } \\
{[68,73,76-78] \text { and }} \\
\text { transport }[69] .\end{array}$ \\
\hline $\begin{array}{c}\text { Unfinish } \\
\text { Literature, Media }\end{array}$ & $\begin{array}{l}\text { Waterfront } \\
\text { rehabilitation } \\
\text { completed and } \\
\text { further continued } \\
\text { northeast (2004 } \\
\text { Forum of Cultures) } \\
\text { [9] (p. 1031). }\end{array}$ & $\begin{array}{l}\text { The village is } \\
\text { inhabited, the } \\
\text { natural parks } \\
\text { opened to the public } \\
\text { and venues being } \\
\text { operated (but low } \\
\text { demand) [21]. }\end{array}$ & $\begin{array}{l}\text { Venue operation } \\
\text { projects approved } \\
\text { yet stalled [1] } \\
\text { (p. 334). } \\
\text { Continuation only } \\
\text { after several } \\
\text { years [29]. }\end{array}$ & $\begin{array}{l}\text { Projects stalled, } \\
\text { incomplete or } \\
\text { awaiting licenses } \\
\text { and funding [1] } \\
\text { (p. 334) [33]. }\end{array}$ & $\begin{array}{l}\text { Commercialization } \\
\text { of housing [95] } \\
\text { (p. 130); ; post-event } \\
\text { adaptation; new } \\
\text { projects developed } \\
\text { (e.g., for Beijing2022) } \\
\text { [97]. }\end{array}$ & $\begin{array}{l}\text { Final quality below } \\
\text { expected but } \\
\text { adjustments allowed } \\
\text { for completion and } \\
\text { viability }[48,51] .\end{array}$ & $\begin{array}{l}\text { Some venues } \\
\text { removed or } \\
\text { relocated and others } \\
\text { in operation. } \\
\text { Housing project } \\
\text { being developed as } \\
\text { expected [53-55]. }\end{array}$ & $\begin{array}{l}\text { Venues not used as } \\
\text { planned and } \\
\text { intended relocations } \\
\text { did not go forward } \\
\text { [63] (p. 341). }\end{array}$ & $\begin{array}{l}\text { Many planned } \\
\text { reconfigurations or } \\
\text { relocations not } \\
\text { carried out [74]. } \\
\text { Undeveloped } \\
\text { housing in the } \\
\text { Park [78]. }\end{array}$ \\
\hline $\begin{array}{c}\text { Improvise } \\
\text { Literature, Media }\end{array}$ & $\begin{array}{l}\text { The Games served } \\
\text { for a partial } \\
\text { intervention } \\
\text { integrated in a } \\
\text { city-wide project [8] } \\
\text { (p. 1332). }\end{array}$ & $\begin{array}{l}\text { SOPA was created to } \\
\text { replace Games' } \\
\text { entities and } \\
\text { developed a plan for } \\
\text { the site immediately } \\
\text { after the event [24] } \\
\text { (p. 1630). }\end{array}$ & $\begin{array}{l}\text { No proper strategic } \\
\text { planning for the } \\
\text { period after the } \\
\text { Games [1] (p. 322). }\end{array}$ & $\begin{array}{l}\text { Plan for the } \\
\text { post-event use of } \\
\text { venues incomplete } \\
\text { and established only } \\
\text { after the Games [89] } \\
\text { (pp. 2-3). }\end{array}$ & $\begin{array}{l}\text { For-profit uses } \\
\text { awarded to consortia } \\
\text { carrying out } \\
\text { conception-building- } \\
\text { operation. Most } \\
\text { venues successful } \\
{[95,96] \text {. }}\end{array}$ & $\begin{array}{l}\text { Post-event operation } \\
\text { compromised in } \\
\text { early construction, } \\
\text { with solutions } \\
\text { showing } \\
\text { improvisation [51]. }\end{array}$ & $\begin{array}{l}\text { Previously planned } \\
\text { site regeneration, } \\
\text { showing a clear } \\
\text { development } \\
\text { strategy (yet affected } \\
\text { by crisis) [54] } \\
\text { (p. 934). }\end{array}$ & $\begin{array}{l}\text { Only general ideas } \\
\text { for uses after the } \\
\text { Games, with no } \\
\text { strategy for } \\
\text { implementation [63] } \\
\text { (p. 340). }\end{array}$ & $\begin{array}{l}\text { Post-event uses } \\
\text { proposed yet with } \\
\text { no proper plans to } \\
\text { be carried out [74]. } \\
\text { Masterplan } \\
\text { compromised [76]. }\end{array}$ \\
\hline
\end{tabular}


Table A6. Cont.

\begin{tabular}{|c|c|c|c|c|c|c|c|c|c|}
\hline $\begin{array}{l}\text { Criteria } \\
\text { Evaluation } \\
\text { Method(s) }\end{array}$ & Parc de Mar & $\begin{array}{c}\text { Sydney } \\
\text { Olympic Park }\end{array}$ & $\begin{array}{l}\text { Faliro Coastal Zone } \\
\text { OC }\end{array}$ & Hellinikon OC & $\begin{array}{l}\text { Olympic Green \& } \\
\text { Forest Park }\end{array}$ & $\begin{array}{c}\text { Vancouver Olympic } \\
\text { Village }\end{array}$ & $\begin{array}{l}\text { Queen Elizabeth } \\
\text { Olympic Park }\end{array}$ & Sochi Olympic Park & Barra Olympic Park \\
\hline $\begin{array}{c}\text { Deflate } \\
\text { Literature, Media }\end{array}$ & $\begin{array}{l}\text { The regeneration } \\
\text { further attracted } \\
\text { new investment and } \\
\text { "snow-balled" [8] } \\
\text { (p. 1331). }\end{array}$ & $\begin{array}{l}\text { Village sold out and } \\
\text { further developed; } \\
\text { but Park struggles to } \\
\text { attract business/ } \\
\text { investment [21]. }\end{array}$ & $\begin{array}{l}\text { Long-planned } \\
\text { project stalled in face } \\
\text { of the economic } \\
\text { crisis, bureaucracy } \\
\text { and failed legacy } \\
\text { [39]. }\end{array}$ & $\begin{array}{l}\text { Large metropolitan } \\
\text { park envisioned but } \\
\text { disagreements and } \\
\text { crisis hindered } \\
\text { further investment } \\
\text { [34]. }\end{array}$ & $\begin{array}{l}\text { Several } \\
\text { developments, } \\
\text { differently purposed, } \\
\text { continued emerging } \\
\text { around or within the } \\
\text { site [47]. }\end{array}$ & $\begin{array}{l}\text { Disappointing } \\
\text { price-quality forced } \\
\text { price reduction of } \\
\text { one-third to ensure } \\
\text { viability [51] } \\
\text { (pp. 67-68). }\end{array}$ & $\begin{array}{l}\text { Continues to attract } \\
\text { investment for the } \\
\text { development of } \\
\text { housing and other } \\
\text { activities [53]. }\end{array}$ & $\begin{array}{l}\text { Promotion efforts } \\
\text { kept attracting assets } \\
\text { for tourism/events } \\
\text { (but better result was } \\
\text { expected) [66]. }\end{array}$ & $\begin{array}{l}\text { Park closure; } \\
\text { housing } \\
\text { development not } \\
\text { carried out; only few } \\
\text { village units sold } \\
\text { out [72,78,79]. }\end{array}$ \\
\hline $\begin{array}{c}\text { Dictate } \\
\text { Literature, Media }\end{array}$ & $\begin{array}{l}\text { No prior } \\
\text { participation or } \\
\text { consultation. } \\
\text { Affected people } \\
\text { consulted during } \\
\text { works [45] (p. 100). }\end{array}$ & $\begin{array}{l}\text { Some, yet limited, } \\
\text { consultation through } \\
\text { setting up of SIAC to } \\
\text { report to the } \\
\text { Minister [45] } \\
\text { (p. 141). }\end{array}$ & \multicolumn{2}{|c|}{$\begin{array}{l}\text { Civil society not included in the planning } \\
\text { process (justified by schedules and cost } \\
\text { overruns) [45] (p. 145). }\end{array}$} & $\begin{array}{l}\text { No public outreach } \\
\text { congruent with the } \\
\text { lack of freedom of } \\
\text { expression [45] (pp. } \\
168,821-822) \text {. }\end{array}$ & $\begin{array}{l}\text { Public consultation } \\
\text { of communities } \\
\text { during the planning } \\
\text { processes [45] } \\
\text { (pp. 193). }\end{array}$ & $\begin{array}{l}\text { Organizers receptive } \\
\text { to demands from } \\
\text { citizens' associations } \\
\text { [45] (pp. 176-177). }\end{array}$ & $\begin{array}{l}\text { Laws amended to } \\
\text { carry out any type of } \\
\text { construction; abuse } \\
\text { of power for } \\
\text { cooperation [64] } \\
\text { (p. 215). }\end{array}$ & $\begin{array}{l}\text { No discussion with } \\
\text { residents on eviction } \\
\text { plans nor } \\
\text { negotiation for } \\
\text { resettlement [71] } \\
\text { (p. 1145). }\end{array}$ \\
\hline $\begin{array}{c}\text { Pave-over } \\
\text { Virtual site survey, } \\
\text { Time-lapse imagery } \\
\text { analysis }\end{array}$ & $\begin{array}{l}\text { Despite dense } \\
\text { urbanization, the } \\
\text { project included } \\
\text { several urban greens } \\
\text { and preserved } \\
\text { beaches. }\end{array}$ & $\begin{array}{l}\text { Park preserved large } \\
\text { areas of natural } \\
\text { wetland; urban areas } \\
\text { with good provision } \\
\text { of green spaces. }\end{array}$ & $\begin{array}{l}\text { When concluded, } \\
\text { the project will have } \\
\text { created a large green } \\
\text { park at the } \\
\text { waterfront. }\end{array}$ & $\begin{array}{l}\text { Failed to remediate } \\
\text { the mostly } \\
\text { impervious site. No } \\
\text { commitment yet to } \\
\text { convert to a forest } \\
\text { park. }\end{array}$ & $\begin{array}{l}\text { The project created } \\
\text { the city's largest } \\
\text { Forest Park, } \\
\text { including restored } \\
\text { marshland. }\end{array}$ & $\begin{array}{l}\text { The Olympic Village } \\
\text { improved the } \\
\text { provision of green } \\
\text { spaces regarding the } \\
\text { earlier land use. }\end{array}$ & $\begin{array}{l}\text { The Queen Elizabeth } \\
\text { Olympic Park } \\
\text { converted } \\
\text { brownfield to green } \\
\text { areas. }\end{array}$ & $\begin{array}{l}\text { Park almost entirely } \\
\text { impervious; some } \\
\text { construction over } \\
\text { diverted and } \\
\text { culverted creeks and } \\
\text { wetlands. }\end{array}$ & $\begin{array}{l}\text { The Barra Olympic } \\
\text { Park is composed } \\
\text { almost entirely of } \\
\text { impervious surfaces. }\end{array}$ \\
\hline $\begin{array}{c}\text { Obstruct } \\
\text { Virtual site survey, } \\
\text { Time-lapse imagery } \\
\text { analysis }\end{array}$ & $\begin{array}{l}\text { New breakwaters } \\
\text { introduced to } \\
\text { prevent beach } \\
\text { erosion, affecting } \\
\text { longshore sediment } \\
\text { circulation. }\end{array}$ & $\begin{array}{l}\text { Preserved, improved } \\
\text { and restored } \\
\text { connectivity to } \\
\text { wetlands. }\end{array}$ & $\begin{array}{l}\text { Artificial flood } \\
\text { discharge channels } \\
\text { that flow into the } \\
\text { area pre-date the } \\
\text { Olympic } \\
\text { intervention. }\end{array}$ & $\begin{array}{l}\text { Inland hydrological } \\
\text { system already } \\
\text { altered before, but } \\
\text { new port's } \\
\text { breakwater affects } \\
\text { longshore. }\end{array}$ & $\begin{array}{l}\text { The reinvented river } \\
\text { channel resorts to } \\
\text { dams and weirs to } \\
\text { sustain lake and } \\
\text { regulate water flow. }\end{array}$ & $\begin{array}{l}\text { No significant } \\
\text { breakwaters or } \\
\text { pontoons } \\
\text { introduced. }\end{array}$ & $\begin{array}{l}\text { No significant new } \\
\text { weirs or dams } \\
\text { introduced to the } \\
\text { already modified } \\
\text { river. }\end{array}$ & $\begin{array}{l}\text { Alteration of natural } \\
\text { longshore with new } \\
\text { port structures. } \\
\text { Small creeks and } \\
\text { wetlands culverted. }\end{array}$ & $\begin{array}{l}\text { No significant new } \\
\text { weirs or pontoons } \\
\text { introduced. }\end{array}$ \\
\hline $\begin{array}{c}\text { Armor } \\
\text { Virtual site survey, } \\
\text { Time-lapse imagery } \\
\text { analysis }\end{array}$ & $\begin{array}{l}\text { Most coastal } \\
\text { protection through } \\
\text { hard defense } \\
\text { structures pre-dated } \\
\text { the Olympic } \\
\text { intervention. }\end{array}$ & $\begin{array}{l}\text { Seawalls preserved } \\
\text { and reinforced, but } \\
\text { no significant new } \\
\text { flood defense } \\
\text { structures } \\
\text { introduced. }\end{array}$ & $\begin{array}{l}\text { Created over } \\
\text { existing and new } \\
\text { landfill. Very limited } \\
\text { adoption of passive } \\
\text { flood management. }\end{array}$ & $\begin{array}{l}\text { No major new flood } \\
\text { control works } \\
\text { introduced outside } \\
\text { the new marina. }\end{array}$ & $\begin{array}{l}\text { Riprap and hard } \\
\text { embankment but } \\
\text { most of the Park acts } \\
\text { as floodplain } \\
\text { (passive detention). }\end{array}$ & $\begin{array}{l}\text { Seawalls formalized, } \\
\text { but hard defense } \\
\text { structures already } \\
\text { present before the } \\
\text { intervention. }\end{array}$ & $\begin{array}{l}\text { No new major } \\
\text { defense structures. } \\
\text { Small patches of } \\
\text { restored floodplain } \\
\text { and wetland. }\end{array}$ & $\begin{array}{l}\text { New hard coastal } \\
\text { defense structures, } \\
\text { including a levee } \\
\text { along the seafront } \\
\text { and a breakwater. }\end{array}$ & $\begin{array}{l}\text { Existing riprap walls } \\
\text { and landfill were } \\
\text { preserved, but no } \\
\text { significant new } \\
\text { works done. }\end{array}$ \\
\hline $\begin{array}{c}\text { Hide } \\
\text { Virtual site survey, } \\
\text { Time-lapse imagery } \\
\text { analysis }\end{array}$ & $\begin{array}{l}\text { Cleaned-up the } \\
\text { urban beaches and } \\
\text { reconnected them to } \\
\text { the urban fabric. }\end{array}$ & $\begin{array}{l}\text { Preserved and } \\
\text { restored extensive } \\
\text { wetland ecosystems, } \\
\text { promoting ecological } \\
\text { education. }\end{array}$ & $\begin{array}{l}\text { The urban seafront } \\
\text { park does not } \\
\text { propose significant } \\
\text { restoration of coastal } \\
\text { wetland habitat. }\end{array}$ & $\begin{array}{l}\text { No definitive } \\
\text { projects for the } \\
\text { Forest Park, so there } \\
\text { is no present } \\
\text { commitment to } \\
\text { restoration efforts. }\end{array}$ & $\begin{array}{l}\text { The project created a } \\
\text { large Forest Park } \\
\text { that includes } \\
\text { extensive areas of } \\
\text { restored marshland. }\end{array}$ & $\begin{array}{l}\text { Small patches of } \\
\text { local beach habitat } \\
\text { were preserved and } \\
\text { restored. }\end{array}$ & $\begin{array}{l}\text { The Lower Lea was } \\
\text { cleaned-up and } \\
\text { small patches of } \\
\text { riparian vegetation } \\
\text { reintroduced. }\end{array}$ & $\begin{array}{l}\text { Replaced beach with } \\
\text { hard seawall. Parts } \\
\text { developed over } \\
\text { marshland and } \\
\text { riparian vegetation. }\end{array}$ & $\begin{array}{l}\text { Rim of mangrove } \\
\text { forest preserved, but } \\
\text { the opportunity to } \\
\text { expand their area } \\
\text { was not explored. }\end{array}$ \\
\hline $\begin{array}{c}\text { Disconnect } \\
\text { Virtual site survey }\end{array}$ & $\begin{array}{l}\text { Access to the } \\
\text { beaches was vastly } \\
\text { improved by the } \\
\text { intervention. }\end{array}$ & $\begin{array}{l}\text { Access to the } \\
\text { waterfront promoted } \\
\text { via public transit, } \\
\text { local street and } \\
\text { pedestrian walks. }\end{array}$ & $\begin{array}{l}\text { The project includes } \\
\text { at least three level } \\
\text { crossings to the } \\
\text { waterfront and a } \\
\text { large seafront park. }\end{array}$ & $\begin{array}{l}\text { No significant } \\
\text { improvement in } \\
\text { access to the seafront } \\
\text { from the site. }\end{array}$ & $\begin{array}{l}\text { Urban park } \\
\text { accessible by public } \\
\text { transit; pedestrian } \\
\text { circuits centered } \\
\text { around recreated } \\
\text { river system. }\end{array}$ & $\begin{array}{l}\text { Waterfront fully } \\
\text { accessible; treated as } \\
\text { a quality public } \\
\text { space and supported } \\
\text { by a pedestrian } \\
\text { system. }\end{array}$ & $\begin{array}{l}\text { Centered around the } \\
\text { river, with systems } \\
\text { of pedestrian paths } \\
\text { (encourages access } \\
\text { to/across/along it). }\end{array}$ & $\begin{array}{l}\text { No significant } \\
\text { improvement. } \\
\text { Central part visually } \\
\text { disconnected from } \\
\text { seafront. }\end{array}$ & $\begin{array}{l}\text { Main axis directs } \\
\text { pedestrians to the } \\
\text { Lagoon, but no } \\
\text { pedestrian walk } \\
\text { along the waterfront }\end{array}$ \\
\hline
\end{tabular}




\section{References}

1. Gold, J.R.; Gold, M.M. Olympic Cities: City Agendas, Planning and the World's Games, 1896-2016, 2nd ed.; Routledge: London, UK, 2011.

2. Hiller, H.H. Post-event Outcomes and the Post-modern Turn: The Olympics and Urban Transformations. Eur. Sport Manag. Q. 2006, 6, 317-332. [CrossRef]

3. Müller, M. The Mega-Event Syndrome: Why So Much Goes Wrong in Mega-Event Planning and What to Do About It. J. Am. Plan. Assoc. 2015, 81, 6-17. [CrossRef]

4. Kassens-Noor, E. From Ephemeral Planning to Permanent Urbanism: An Urban Planning Theory of Mega-Events. Urban Plan. 2016, 1, 41-54. [CrossRef]

5. Lauermann, J. "The city" as developmental justification: Claimsmaking on the urban through strategic planning. Urban Geogr. 2016, 37, 77-95. [CrossRef]

6. $\quad$ Essex, S.; Chalkley, B. Olympic Games: Catalyst of urban change. Leis. Stud. 1998, 17, 187-206. [CrossRef]

7. Lopes dos Santos, G.; Gonçalves, J. The Olympic Effect in strategic planning: Insights from candidate cities. Plan. Perspect. 2021, 1-25. [CrossRef]

8. Garcia-Ramon, M.D.; Albet, A. Pre-Olympic and post-Olympic Barcelona, a 'model' for urban regeneration today? Environ. Plan. A 2000, 32, 1331-1334. [CrossRef]

9. Degen, M.; Garcia, M. The Transformation of the 'Barcelona Model': An Analysis of Culture, Urban Regeneration and Governance. Int. J. Urban Reg. Res. 2012, 36, 1022-1038. [CrossRef]

10. Müller, M.; Wolfe, S.D.; Gogishvili, D.; Gaffney, C.; Hug, M.; Leick, A. An evaluation of the sustainability of the Olympic Games. Nat. Sustain. 2021, 4, 340-348. [CrossRef]

11. Chappelet, J.L. Olympic Environmental Concerns as a Legacy of the Winter Games. Int. J. Hist. Sport 2008, 25, 1884-1902. [CrossRef]

12. Flyvbjerg, B.; Budzier, A.; Lunn, D. Regression to the tail: Why the Olympics blow up. Environ. Plan. A Econ. Space 2021, 53, 233-260. [CrossRef]

13. Lopes dos Santos, G.; Gonçalves, J.; Condessa, B.; Nunes da Silva, F.; Delaplace, M. Olympic Charter Evolution Shaped by Urban Strategies and Stakeholder's Governance: From Pierre de Coubertin to the Olympic Agenda 2020. Int. J. Hist. Sport 2021, 38, 545-568. [CrossRef]

14. Mann, R. Rivers in the City, 1st ed.; David \& Charles: Newton Abbott, UK, 1973.

15. Castonguay, S.; Evenden, M. Urban Rivers: Remaking Rivers, Cities, and Space in Europe and North America, 1st ed.; University of Pittsburgh Press: Pittsburgh, PA, USA, 2012.

16. Brownill, S. Just add water: Waterfront regeneration as a global phenomenon. In The Routledge Companion to Urban Regeneration, 1st ed.; Leary, M.E., McCarthy, J., Eds.; Routledge: London, UK, 2013; pp. 65-75.

17. Avni, N.; Teschner, N. Urban waterfronts: Contemporary streams of planning conflicts. J. Plan. Lit. 2019, 34, 408-420. [CrossRef]

18. Pinto, P.J.; Kondolf, G.M. The Fit of Urban Waterfront Interventions: Matters of Size, Money and Function. Sustainability 2020, 12, 4079. [CrossRef]

19. Bruttomesso, R. Waterfront Redevelopment: A Strategic Choice for Cities on Water. Paper Presented at the Waterfront Development Forum: China Maritime, Hong Kong, 2 March 2006. Available online: https:/ /www.harbourbusinessforum.com/ download/060303_transcript.pdf (accessed on 29 December 2021).

20. García, M. The case of Barcelona. In Metropolitan Governance and Spatial Planning: Comparative Studies of European City-Regions, 1st ed.; Salet, W., Thornley, A., Kreukels, A., Eds.; Spon Press: London, UK, 2003; pp. 337-358.

21. The Sydney Morning Herald. How Olympic Park Became Trapped between Sporting Legacy and Reinvention. Available online: https:/ / www.smh.com.au/national/nsw/how-olympic-park-became-trapped-between-sporting-legacy-and-reinvention20200723-p55eti.html (accessed on 29 December 2021).

22. Chen, Y.; Spaans, M. Mega-event strategy as a tool of urban transformation: Sydney's experience. In The New Urban Question: Urbanism beyond Neo-Liberalism, Proceedings of the 4th Conference of International Forum on Urbanism, Amsterdam and Delft, The Netherlands, 26-28 November 2009; International Forum on Urbanism: Delft, The Netherlands, 2009.

23. Searle, G. Uncertain Legacy: Sydney's Olympic Stadiums. Eur. Plan. Stud. 2002, 10, 845-860. [CrossRef]

24. Davidson, M.; McNeill, D. The Redevelopment of Olympic Sites: Examining the Legacy of Sydney Olympic Park. Urban Stud. 2012, 49, 1625-1641. [CrossRef]

25. Architecture AU. Sydney Olympic Park 2030: The City in a Park. Available online: https://architectureau.com/articles/sydneyolympic-park-2030-the-city-in-a-park/ (accessed on 29 December 2021).

26. Greek Reporter. Faliro Regeneration Project Moves Ahead. Available online: https://greekreporter.com/2014/07/19/faliroregeneration-project-moves-ahead/ (accessed on 29 December 2021).

27. The New York Times. The Long-Ignored Athens Waterfront Is Being Revived. Available online: https://www.nytimes.com/2019 /10/01/realestate/athens-waterfront-revival-park.html (accessed on 29 December 2021).

28. Ypodomes. Phase B' Construction Works for Faliro Bay Restoration Project to Be Auctioned in Early 2019. Available online: https: //ypodomes.com/phase-b-construction-works-for-faliro-bay-restoration-project-to-be-auctioned-in-early-2019/ (accessed on 29 December 2021) 
29. Greek Reporter. Plans for Second Phase of Athens Riviera Reconstruction Project Presented. Available online: https: //greekreporter.com/2020/02/04/plans-for-second-phase-of-athens-riviera-reconstruction-project-presented/ (accessed on 29 December 2021).

30. Memim Encyclopedia. Faliro Coastal Zone Olympic Complex. Available online: https://memim.com/faliro-coastal-zoneolympic-complex.html (accessed on 29 December 2021).

31. Beriatos, E.; Gospodini, A. "Glocalising" urban landscapes: Athens and the 2004 Olympics. Cities 2004, 21, 187-202. [CrossRef]

32. Athens Social Atlas. Renovation Projects at Faliro Bay. Available online: https://www.athenssocialatlas.gr/en/article/faliro-bay/ (accessed on 29 December 2021).

33. Komninos, A. Hellinikon and the Question of the Large Urban Void. Master's Thesis, National Technical University of Athens, Athens, Greece, 2010.

34. CNN Travel. The Greek Airport That Was Left to Fall Apart. Available online: https://edition.cnn.com/travel/article/greeceabandoned-airport/index.html (accessed on 29 December 2021).

35. The Ellinikon. Available online: https://theellinikon.com.gr/en/homepage/ (accessed on 29 December 2021).

36. Kasimati, E. Post-Olympic Use of the Olympic Venues: The Case of Greece. Athens J. Sports 2015, 2, 167-184. [CrossRef]

37. Kissoudi, P. The Athens Olympics: Optimistic Legacies-Post-Olympic Assets and the Struggle for their Realization. Int. J. Hist. Sport 2008, 25, 1972-1990. [CrossRef]

38. Boukas, N.; Ziakas, V.; Boustras, G. Olympic legacy and cultural tourism: Exploring the facets of Athens' Olympic heritage. Int. J. Herit. Stud. 2013, 19, 203-228. [CrossRef]

39. Souliotis, N.; Sayas, J.; Maloutas, T. Megaprojects, Neoliberalization, and State Capacities: Assessing the Medium-Term Impact of the 2004 Olympic Games on Athenian Urban Policies. Environ. Plan. C Politics Space 2014, 32, 731-745. [CrossRef]

40. The Field. Olympic Sustainable Landscapes: The Case of Beijing. Available online: https://thefield.asla.org/2021/03/02 / olympic-sustainable-landscapes-the-case-of-beijing/ (accessed on 29 December 2021).

41. Berkowitz, P.; Gjermano, G.; Gomez, L.; Schafer, G. Brand China: Using the 2008 Olympic Games to enhance China's image. Place Branding Public Dipl. 2007, 3, 164-178. [CrossRef]

42. Broudehoux, A.M. Spectacular Beijing: The Conspicuous Construction of an Olympic Metropolis. J. Urban Aff. 2007, 29, 383-399. [CrossRef]

43. Landscape Performance Series. Beijing Olympic Forest Park. Available online: https://www.landscapeperformance.org/casestudy-briefs / beijing-olympic-forest-park\#/lessons-learned (accessed on 29 December 2021).

44. NPR. China's Post-Olympic Woe: How to Fill an Empty Nest. Available online: https://www.npr.org/2012/07/10/156368611 / chinas-post-olympic-woe-how-to-fill-an-empty-nest?t=1640523519676 (accessed on 29 December 2021).

45. Centre on Housing Rights and Evictions (COHRE). Fair Play for Housing Rights: Mega-Events, Olympic Games and Housing Rights; COHRE: Geneva, Switzerland, 2007.

46. Sasaki. The Olympics: Past, Present, and Future. Available online: https://www.sasaki.com/voices/the-olympics-past-presentand-future/ (accessed on 29 December 2021).

47. International Olympic Committee. Legacies Live on in “New Beijing”. Available online: https://olympics.com/ioc/news/ legacies-live-on-in-new-beijing (accessed on 29 December 2021).

48. Westerhoff, L.M. Emerging Narratives of a Sustainable Urban Neighbourhood: The Case of Vancouver's Olympic Village. Artic. J. Urban Res. 2016, 14. [CrossRef]

49. Porter, L. Planning Displacement: The Real Legacy of Major Sporting Events. Plan. Theory Pract. 2009, 10, 395-418. [CrossRef]

50. Pentifallo, C.; VanWynsberghe, R. Mega-event impact assessment and policy attribution: Embedded case study, social housing, and the 2010 Winter Olympic Games. J. Policy Res. Tour. Leis. Events 2015, 7, 266-281. [CrossRef]

51. McCarthy, W.P.J. The Failed Experiment of Vancouver's 2010 Olympic Village. Real Estate Issues 2012, 37, 60-76.

52. Scherer, J. Olympic Villages and Large-scale Urban Development: Crises of Capitalism, Deficits of Democracy? Sociology 2011, 45, 782-797. [CrossRef]

53. Engineering and Technology. Did London Beat the Olympic Curse? Available online: https://eandt.theiet.org/content/articles/ 2021/06/did-london-beat-the-olympic-curse/ (accessed on 29 December 2021).

54. Bernstock, P. Evaluating the contribution of planning gain to an inclusive housing legacy: A case study of London 2012. Plan. Perspect. 2020, 35, 927-953. [CrossRef]

55. Azzali, S. Queen Elizabeth Olympic Park: An assessment of the 2012 London Games Legacies. City Territ. Archit. $2017,4,11$. [CrossRef]

56. Cohen, P.; Watt, P. London 2012 and the Post-Olympics City: A Hollow Legacy? 1st ed.; Palgrave Macmillan: London, UK, 2017.

57. The Guardian. Displaced by London's Olympics. Available online: https://www.theguardian.com/uk/2008/jun/02/olympics2 012 (accessed on 29 December 2021).

58. Müller, M. State dirigisme in megaprojects: Governing the 2014 Winter Olympics in Sochi. Environ. Plan. A Econ. Space 2011, 43, 2091-2108. [CrossRef]

59. The Interpreter. Winter Olympics in the Sub-Tropics: Corruption and Abuse in Sochi. Available online: https://www. interpretermag.com/winter-olympics-in-the-sub-tropics-corruption-and-abuse-in-sochi/ (accessed on 29 December 2021).

60. Müller, M. After Sochi 2014: Costs and impacts of Russia's Olympic Games. Eurasian Geogr. Econ. 2014, 55, 628-655. [CrossRef] 
61. ArchDaily. Why Putin Likes Columns: 21st Century Russia through the Lens of Architecture. Available online: https: //www.archdaily.com/587275/why-putin-likes-columns-21st-century-russia-through-the-lens-of-architecture (accessed on 29 December 2021).

62. Nickell, W. Olympian Plans and Ruins: The Makeover of Sochi. Rev. Études Slaves 2015, 86, 97-112. [CrossRef]

63. Azalli, S. The legacies of Sochi 2014 Winter Olympics: An evaluation of the Adler Olympic Park. Urban Res. Pract. 2017, 10, 329-349. [CrossRef]

64. O'hara, M. 2014 Winter Olympics in Sochi: An Environmental and Human-Rights Disaster. In The State of Environmental Migration 2015: A Review of 2014; Gemenne, F., Zickgraf, C., Ionesco, D., Eds.; International Organization for Migration (IOM): Geneva, Switzerland, 2015; pp. 203-220.

65. Time. Weird, Wonderful Sochi: Inside Russia's Own Palm Beach. Available online: https://time.com/3806933/sochi-russiaolympics-village/ (accessed on 29 December 2021).

66. France 24. How the 2014 Winter Olympics Transformed Sochi. Available online: https://www.france24.com/en/revisited/2018 0215-sochi-russia-olympic-games-economy-tourism-putin (accessed on 29 December 2021).

67. International Olympic Committee. Olympic Legacies Live on in Russia. Available online: https://olympics.com/ioc/news/ olympic-legacies-live-on-in-russia (accessed on 29 December 2021).

68. The Atlantic. The Broken Promise of the Rio Olympics. How a Chance to Remake the City for Ordinary Brazilians Ended Up Lining the Pockets of the Rich Instead. Available online: https://www.theatlantic.com/international/archive/2016/08/buildingbarra-rio-olympics-brazil/493697/ (accessed on 29 December 2021).

69. Kassens-Noor, E.; Gaffney, C.; Messina, J.; Phillips, E. Olympic Transport Legacies: Rio de Janeiro's Bus Rapid Transit System. J. Plan. Educ. Res. 2018, 38, 13-24. [CrossRef]

70. Globo. Legado Olímpico: Sistema BRT, Promessa de Solução para o Transporte, Tem Estações Depredadas e Ônibus Superlotados. Available online: https://g1.globo.com/rj/rio-de-janeiro/noticia/2021/07/22/legado-olimpico-sistema-brt-promessade-solucao-para-o-transporte-tem-estacoes-depredadas-e-onibus-superlotados.ghtml (accessed on 29 December 2021).

71. Gaffney, C. Gentrifications in pre-Olympic Rio de Janeiro. Urban Geogr. 2016, 37, 1132-1153. [CrossRef]

72. RTE. Rio Continues to Pay the Price for Its 2016 Olympic Odyssey. Available online: https://www.rte.ie/news / 2021/0716/1235 401-rio-olympics / (accessed on 29 December 2021).

73. Consultor Jurídico. Legado Olímpico: União pede Condenação do Rio por Problemas nas Obras das Olimpíadas. Available online: https:/ / www.conjur.com.br/2019-abr-20/uniao-condenacao-rio-problemas-obras-olimpiadas (accessed on 29 December 2021).

74. The Tennessee Tribune. The Olympics' Legacy: From Lost Investment to Corruption Allegations. Available online: https: // tntribune.com/the-olympics-legacy-from-lost-investment-to-corruption-allegations / (accessed on 29 December 2021).

75. Veja. Ao Menos R\$ 80 Milhões desde 2012: O Custo do Legado Olímpico do Rio. Available online: https://veja.abril.com.br/ coluna/maquiavel/ao-menos-r-80-milhoes-desde-2017-o-custo-do-legado-olimpico-do-rio/ (accessed on 29 December 2021).

76. Sanchez, R.L.O. Desenhando o Urbano: Legado das Olimpíadas Rio 2016 na Barra da Tijuca. In All the worlds. Just one world. Architecture 21. Proceedings of the UIA 2021 Rio: 27th World Congress of Architects, Rio de Janeiro, Brazil, 18-22 July 2021; UIA 2021 Rio: Rio de Janeiro, Brazil, 2021; pp. 694-701.

77. Furtado, L.; Antonovz, T.; Peixe, B.; Correa, M. The role of the audit in the prevention and detection of corruption events: Evidence of the 2016 Rio Olympic Games. Intang. Cap. 2020, 16, 14-30. [CrossRef]

78. O'Donnell, J.; Amaral de Sampaio, L.; Cavalcanti, M. Entre futuros e ruínas: Os caminhos da Barra Olímpica. Dilemas Rev. Estud. Confl. Controle Soc. 2020, 13, 119-146.

79. Globo. Após 3 Anos da Rio 2016, Vila dos Atletas Vendeu Menos de 15\% dos Apartamentos Construídos. Available online: https:/ /g1.globo.com/rj/rio-de-janeiro/noticia/2019/08/12/apos-3-anos-da-rio-2016-vila-dos-atletas-vendeu-menosde-15percent-dos-apartamentos-construidos.ghtml (accessed on 29 December 2021).

80. House Beautiful. Here's What Will Become of the Tokyo Olympic Village after the Games Are Over. Available online: https: / / www.housebeautiful.com/lifestyle/a37246699/tokyo-olympic-village-future-harumi-flag/ (accessed on 29 December 2021).

81. The Guardian. Tokyo's Olympic Architecture: Look, no Bird's Nest ... . Available online: https://www.theguardian.com/ artanddesign/2021/jul/18/tokyo-olympics-2020-new-buildings (accessed on 29 December 2021).

82. Lopes dos Santos, G.; Condessa, B.; Nunes da Silva, F.; Delaplace, M. Olympic Agenda 2020: Effects on the Games' Urban Concept. Grand Projects. In Proceedings of the Grand Projects: Urban Legacies of the Late 20th Century, Lisbon, Portugal, 17-19 February 2021; Tormenta Pinto, P., Brandão, A., Silva Lopes, S., Eds.; DINÂMIA'CET: Lisbon, Portugal, 2021; pp. 85-98. Available online: https:/ / www.grandprojects2021.com/programme (accessed on 29 December 2021).

83. Des Ouvrages, Notre Héritage. Athletes' Village. Available online: https:// projets.ouvrages-olympiques.fr/en/athletes-village/ (accessed on 29 December 2021).

84. Brisbane Times. First Look at Brisbane's 2032 Olympic Athletes' Village. Available online: https://www.brisbanetimes. com.au/national/queensland/first-look-at-brisbane-s-2032-olympics-athletes-village-20210728-p58dk1.html (accessed on 29 December 2021).

85. Architectural Digest. The Best Olympic Architecture. Available online: https://www.architecturaldigest.com/gallery/bestolympic-architecture-beijing-athens-barcelona-slideshow (accessed on 29 December 2021).

86. ArchDaily. Olympic Urbanism: The Afterlife of Olympic Parks and Stadiums. Available online: https://www.archdaily.com/96 4471/olympic-urbanism-the-afterlife-of-olympic-parks-and-stadiums (accessed on 29 December 2021). 
87. Architectural Record. Vancouver's Olympic Village Aims High on Sustainability Scale. Available online: https:// www.architecturalrecord.com/articles/4949-vancouver-s-olympic-village-aims-high-on-sustainability-scale (accessed on 29 December 2021).

88. Kaitantzian, A.; Loupasakis, C.; Tzampoglou, P.; Parcharidis, I. Ground Subsidence Triggered by the Overexploration of Aquifers Affecting Urban Sites: The Case of Athens Coastal Zone along Faliro Bay (Greece). Geofluids 2020, 2020, 8896907. [CrossRef]

89. Okada, I.; Greyser, S.A. After the Carnival: Key Factors to Enhance Olympic Legacy and Prevent Olympic Sites from Becoming White Elephants; Working Paper; Harvard Business School Working Knowledge: Boston, MA, USA, 2018.

90. Barcelona Metropolitan. 6 Ways the 1992 Olympics Transformed Barcelona. Available online: https://www.barcelonametropolitan.com/features/6-ways-the-1992-olympics-transformed-barcelon/ (accessed on 29 December 2021).

91. Papanikolaou, P. Athens 2004. Ten Years Later the Olympic Infrastructure, the Cultural Olympiad and the 'White Elephant' Syndrome. J. Power Politics Gov. 2013, 1, 1-9.

92. Jefferies, M.; Gameson, R.; Rowlinson, S. Critical success factors of the BOOT procurement system: Reflections from the Stadium Australia case study. Eng. Constr. Archit. Manag. 2002, 9, 352-361. [CrossRef]

93. Jefferies, M. Critical success factors of public private sector partnerships. A case study of the Sydney SuperDome. Eng. Constr. Archit. Manag. 2006, 13, 451-462. [CrossRef]

94. Marinelli, M.; Petroutsatou, K.; Fragkakis, N.; Lambropoulos, S. Rethinking new public infrastructure value for money in recession times: The Greek case. Int. J. Constr. Manag. 2018, 18, 331-342. [CrossRef]

95. Shin, H.B. Life in the shadow of mega-events: Beijing Summer Olympiad and its impact on housing. J. Asian Public Policy 2009, 2, 122-141. [CrossRef]

96. Liang, W.; Song, X.; Wang, S. Case Study of the Bird's Nest: Risks and Opportunities in China's Ppp Implementations in Major Sports Facilities. Adv. Mater. Res. 2011, 243-249, 6332-6338. [CrossRef]

97. Team USA. An Inside Look at the Three Zones of the 2022 Winter Olympic Games. Available online: https:/ /www.teamusa. org/News/2021/October/28/An-Inside-Look-At-The-Three-Zones-Of-The-2022-Winter-Olympic-Games (accessed on 29 December 2021). 